
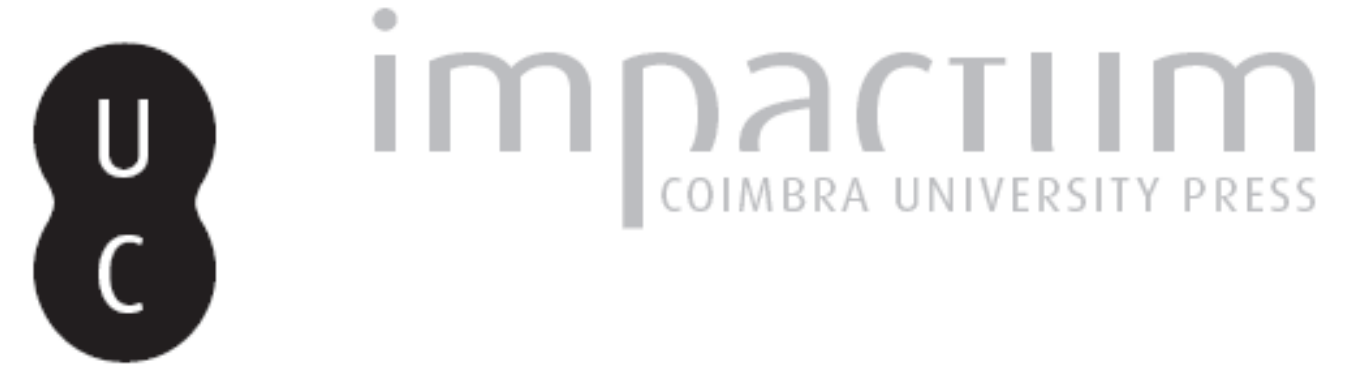

\title{
A fiscalidade directa no Mercado Interno Europeu: problemas colocados pelos regimes complementares de Segurança Social
}

\author{
Autor(es): $\quad$ Martins, Maria Inês de Oliveira \\ Publicado por: Faculdade de Direito da Universidade de Coimbra \\ URL \\ persistente: \\ URI:http://hdl.handle.net/10316.2/24746 \\ DOI: \\ http://dx.doi.org/10.14195/0870-4260_51_4 \\ Accessed : $\quad$ 26-Apr-2023 14:16:56
}

A navegação consulta e descarregamento dos títulos inseridos nas Bibliotecas Digitais UC Digitalis, UC Pombalina e UC Impactum, pressupõem a aceitação plena e sem reservas dos Termos e Condições de Uso destas Bibliotecas Digitais, disponíveis em https://digitalis.uc.pt/pt-pt/termos.

Conforme exposto nos referidos Termos e Condições de Uso, o descarregamento de títulos de acesso restrito requer uma licença válida de autorização devendo o utilizador aceder ao(s) documento(s) a partir de um endereço de IP da instituição detentora da supramencionada licença.

Ao utilizador é apenas permitido o descarregamento para uso pessoal, pelo que o emprego do(s) título(s) descarregado(s) para outro fim, designadamente comercial, carece de autorização do respetivo autor ou editor da obra.

Na medida em que todas as obras da UC Digitalis se encontram protegidas pelo Código do Direito de Autor e Direitos Conexos e demais legislação aplicável, toda a cópia, parcial ou total, deste documento, nos casos em que é legalmente admitida, deverá conter ou fazer-se acompanhar por este aviso.

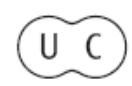




\section{UNIVERSIDADE DE COIMBRA \\ FACULDADE DE DIREITO}

BOLETIII DE CÊACCLS ECONÓNCACAS

VOLUME LI

$\begin{array}{llll}2 & 0 & 0 & 8\end{array}$

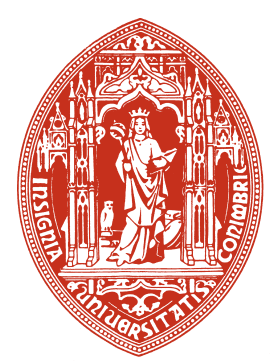

COIMBRA 


\section{A FISCALIDADE DIRECTA NO MERCADO INTERNO EUROPEU \\ - PROBLEMAS COLOCADOS PELOS REGIMES COMPLEMENTARES DE SEGURANÇA SOCIAL}

\section{OS PROBLEMAS}

1. Os regimes complementares de pensão: considerações introdutórias

O presente trabalho ${ }^{1}$ pretende analisar os problemas colocados em sede de integração europeia pela fiscalidade dos regimes complementares de pensão dos vários Estados-Membros.

O que impõe, desde logo, várias precisões. Em primeiro lugar, deve dizer-se que esta questão se integra naquela mais lata da organização de esquemas privados de garantia de um sujeito contra eventos atinentes à sua esfera pessoal - numa terminologia específica desta sede, "riscos sociais", muitos

${ }_{1} \mathrm{O}$ texto que agora se publica corresponde, com muito ligeiras modificações, ao relatório apresentado no ano escolar 2006/2007 do Curso de Mestrado em Ciências Jurídico-Económicas da Faculdade de Direito da Universidade de Coimbra, na disciplina de Comércio Internacional.

${ }^{2}$ Empregando a expressão neste sentido, Oliverra, Arnaldo Filipe da Costa, Fundos de Pensões. Estudo Jurídico, Almedina, 2003, pp. 93 e ss., 
deles consubstanciando riscos biométricos - que afectem a sua capacidade de auferir rendimento. O que se materializa na contribuição do sujeito para um esquema que, na eventualidade da concretização de um daqueles riscos, lhe garanta o pagamento de um rendimento substitutivo do rendimento do trabalho - uma pensão.

No quadro dos actuais modelos de Estado-Providência, essa pensão é tipicamente atribuída pelo Estado, através da Segurança Social estadual. Assim, este sistema estatal de previdência social corresponde a um primeiro pilar $^{3}$ da Segurança Social, que, caracteristicamente ${ }^{4}$, apenas a título

e bibliografia aí citada. Faz-se notar que alguma doutrina considera que o risco, enquanto elemento típico do contrato de seguro, não se adequa a enquadrar a relação de um sujeito com a Segurança Social. Assim, Maurizio Cinelli considera que o sujeito é protegido face a determinados eventos, objectivamente considerados, que nele gerem uma situação de necessidade socialmente relevante; a protecção persiste mesmo que a verificação do evento (vg., doença crónica de que o trabalhador seja portador) fosse já conhecia ao tempo da constituição da relação de protecção - o que não permite descortinar a existência de um risco (CINelli, Maurizio, Diritto della Previdenza Sociale, Giappichelli Editore, 2003).

3 Trata-se do sistema estatal de base, no qual a participação é geralmente universal e compulsória. Baseando-se num princípio de solidariedade entre gerações, o sistema financiar-se-á através de um princípio de repartição (pay-as-you-go), ao abrigo do qual as pensões pagas em cada ano são financiadas pelas contribuições que tenham sido impostas nesse ano à população activa, e não pelas contribuições impostas aos beneficiários enquanto membros da população activa. $\mathrm{O}$ pagamento das correspondentes pensões é garantido pelo Estado, sendo o esquema administrado por uma instituição pública. Cfr., quanto à matéria, a primeira obra citada na nota anterior; para uma enunciação das características destes esquemas, e respectiva apreciação, ver o Livro Verde da Comissão da UE sobre Pensões Complementares no Mercado Único (Comissão, 1997, Supplementary Pensions in the Single Market, COM (97) 283).

${ }^{4}$ Mas não exclusivamente: o segundo pilar conhece hipóteses de verdadeiros esquemas substitutivos dos esquemas de primeiro pilar da 
complementar é integrado pelos sistemas privados do segundo e terceiro pilares da Segurança Social ${ }^{5}$. A nível comunitário, este primeiro pilar da Segurança Social encontra-se enquadrado pelo Regulamento $1408 / 71^{6}$, que procede à coordenação dos regimes estatais de segurança social aplicáveis aos trabalhadores assalariados, aos trabalhadores não assalariados e aos membros da sua família que se deslocam no interior da Comunidade.

Ao segundo pilar da Segurança Social correspondem os esquemas "profissionais" ou "ocupacionais", constituídos ao nível das empresas, grupos de empresas ou outros organismos de carácter associativo. São tipicamente financiados mediante a capitalização de contribuições efectuadas tanto pelo empregado, como pelo empregador.

Por sua vez, os esquemas de pensões do terceiro pilar constituem esquemas de previdência individual, sendo exclusivamente alimentados por contribuições efectuadas pelo

Segurança Social - pense-se, por exemplo, no sistema de fundos de pensões das instituições de crédito vigente em Portugal.

${ }^{5}$ Faz-se notar que têm surgido iniciativas que pretendem associar, aos referidos três pilares da Segurança Social, a ideia de um quarto pilar, que assentaria no incentivo à prestação de trabalho a tempo parcial depois de atingida a idade legal de reforma. À remuneração pelo trabalho assim prestado, cada pensionista somaria o direito a uma pensão, também parcial, paga através de um dos três pilares "tradicionais" (quanto à questão, vd. por todos, Geneva Association, "The four pillars program and its evolution 1987-1998», The Geneva Papers on Risk and Insurance: Issues and Practice, A. 23, n. ${ }^{\circ}$ 88, 1998, pp. 446-464) Esta via de financiamento da Segurança Social não se encontra, porém, suficientemente institucionalizada e estruturada entre os Estados-Membros da EU para que se deva considerar a existência deste quarto pilar.

6 Regulamento 1408/71, de 14 de Junho de 1971, relativo à aplicação dos regimes de segurança social aos trabalhadores assalariados e aos membros da sua família que se deslocam no interior da Comunidade, JO L334 de 27.11.1986, na versão consolidada resultante das várias alterações ao texto inicial. 
próprio interessado, que selecciona o veículo de poupança no âmbito do princípio da autonomia privada.

Num caso, como noutro, os esquemas complementares são administrados por entidades privadas, sem que o Estado surja como garante das pensões futuras ${ }^{7}$. No quadro do segundo pilar, de modo tendencial, e, no quadro do terceiro pilar, de modo absoluto, as pensões correntes são financiadas através da capitalização das contribuições efectuadas pelo próprio beneficiário, ou por conta deste.

Sobre este quadrante da Segurança Social, versa toda uma panóplia de diplomas comunitários, surgindo os termos "plano de pensões", "regime de pensões" e "pensão complementar" em diferentes contextos e acepções. Na presente análise, opta-se pelo uso de uma terminologia alinhada com aquela proposta pela Directiva 98/49/CE ${ }^{8}$, relativa à salvaguarda dos direitos a pensão complementar dos trabalhadores assalariados e independentes ${ }^{9}$ que se deslocam no interior da Comunidade ${ }^{10}{ }^{11}$.

${ }^{7}$ Enquanto rendimento substitutivo do trabalho, o valor atribuído tem, efectivamente, na maioria das vezes, a natureza de pensão tout court, sendo atribuído na forma de prestações regulares e periódicas. No âmbito dos regimes complementares, é, porém, igualmente possível o pagamento de montantes em capital, equivalendo à atribuição ao beneficiário, numa prestação única (lump-sum), da totalidade ou parte dos montantes a que este tem direito. No texto - como na normativa comunitária aqui relevante - usa-se o termo "pensão" numa acepção ampla, apta a abarcar estes dois tipos de atribuição patrimonial.

8 Directiva 98/49/CE do Conselho de 29 de Junho de 1998, relativa à salvaguarda dos direitos a pensão complementar dos trabalhadores assalariados e independentes que se deslocam no interior da Comunidade, JO L209 de 25.07.1998.

9 Tal como a Directiva, no texto far-se-á, em geral, referência a trabalhadores tanto dependentes, como independentes. Por motivos de fluidez de exposição, usar-se-á o termo "trabalhadores" para designar ambos.

${ }^{10}$ A referência terminológica usada mostra-se, desde logo, preferível a uma remissão para a terminologia adoptada pela Proposta de 
Directiva do Parlamento Europeu e do Conselho respeitante às actividades das instituições de realização de planos de pensões profissionais, de 11.10.2000 (COM (2000) 507 final), ou pela Directiva 2003/41/CE do Parlamento Europeu e do Conselho, de 3 de Junho de 2003, relativa às actividades e à supervisão das instituições de realização de planos de pensões profissionais (JO L235 de 23.09.2003, p. 0010-0021), que adoptou aquele primeiro acto. No que não se acompanha a Comunicação da Comissão ao Conselho, ao Parlamento Europeu e ao Comité Económico e Social sobre a Eliminação dos obstáculos fiscais aos regimes de pensões profissionais transfronteiras, de 19.04.2001 (COM (2001) 214 final). Com efeito, os dois primeiros actos citados dirigem-se especificamente à regulamentação dos veículos que, à face do ordenamento jurídico português, adoptam o nomen de fundos de pensões. Deixam, pois, de parte muito do polimorfismo que predica o âmbito dos regimes complementares (cfr. art. 2. ${ }^{\circ}$ da Directiva 2003/41/CE, que introduz várias limitações na definição do respectivo objecto); e deixam principalmente (arts. 2. ${ }^{\circ}$ e $4 .^{\circ}$ da Directiva 2003/41/CE) de parte a figura do seguro de vida que, como melhor se verá, tem protagonizado muita da casuística em matéria de fiscalidade directa dos regimes complementares da Segurança Social.

${ }^{11}$ Além de fornecer uma definição clara dos termos "pensão complementar" e "regime complementar de pensão" a Directiva dota os termos de uma desejável amplitude, mostrando-se apta a abarcar as diversas feições que estes regimes podem adoptar junto das diferentes ordens jurídicas. Isto releva sobretudo no campo do segundo pilar, em que os regimes podem, vg., ser financiados através de um veículo externo de financiamento, ou através da acumulação de reservas registadas no Balanço da própria entidade empregadora, assumir natureza de regime pay-as-you-go (regimes franceses A.G.I.R.C. e A.R.C.O.), ou sofrer a incidência de uma forma mitigada do princípio da solidariedade, ante a previsão de esquemas rudimentares de redistribuição.

A terminologia a que recorre a Directiva 98/49/CE recorre goza ainda de acolhimento junto da mais recente normativa comunitária confronte-se, a título de exemplo, a recente Proposta de Directiva do Parlamento Europeu e do Conselho relativa ao aumento da transferibilidade dos direitos à pensão complementar, de 20.10.2005 (COM(2005) 0507 final). 
Pelo que o termo "pensão complementar" 12 referirá as pensões atribuídas no âmbito do segundo e terceiro pilares da Segurança Social. Por sua vez, a expressão "regime complementar de pensão"13, designará todos os regimes, esquemas, estruturas ou veículos que suportem o pagamento dessas pensões. Assim, na presente análise, com "instituições de pensões" faz-se referência a todas as estruturas aptas a pagar pensões complementares.

\section{A fiscalidade dos regimes complementares de pensão}

\subsection{Estrutura}

Um sujeito passivo que pretenda aplicar uma soma num qualquer esquema de poupança terá, desde logo, sofrido a incidência de impostos sobre o acréscimo patrimonial (designadamente, rendimento) constituído por essa soma, no momento em que esta adveio ao seu património. Com a

${ }^{12}$ Nos termos do art. 3. ${ }^{\circ}$, al. a), da citada Directiva, será pensão complementar "qualquer pensão de reforma e, quando seja concedida ao abrigo das regras de um regime de pensão complementar definido de acordo com a legislação e práticas nacionais, qualquer prestação de invalidez ou de sobrevivência, destinada a completar ou a substituir as prestações concedidas pelos regimes legais de segurança social para as mesmas ocorrências".

${ }^{13}$ Nos termos da al. b) do art. 3. ${ }^{\circ}$ citado na nota anterior, será regime complementar de pensão "qualquer regime profissional de pensão definido de acordo com a legislação e práticas nacionais, nomeadamente os contratos de seguro de grupo, os regimes por repartição concluídos por um ou mais ramos ou sectores, as promessas de pensão garantidas por reservas no balanço das empresas ou quaisquer dispositivos de natureza colectiva ou outros comparáveis destinados a conceder uma pensão complementar a trabalhadores assalariados ou independentes". 
aplicação do montante no esquema pretendido, haverá lugar a novo acréscimo patrimonial, na medida do rendimento gerado pela aplicação. Este acréscimo pode ser sujeito a tributação na esfera do próprio veículo de poupança, no momento em que é gerado; ou pode ser tributado apenas quando for atribuído ao respectivo beneficiário.

Num sistema fiscal que sujeite todos os rendimentos recebidos a tributação, independentemente da sua fonte (regime comprehensive income tax $)^{14}$, os rendimentos aplicados e gerados na poupança estão sujeitos ao mesmo tratamento fiscal que o restante rendimento do sujeito passivo. Ou seja, todos os rendimentos do sujeito passivo serão tributados no momento em que surjam na sua esfera enquanto acréscimo patrimonial. Assim, as aplicações em poupança provirão de rendimento sujeito a tributação (Taxed); e o acréscimo correspondente à frutificação da aplicação efectuada será sujeito

${ }^{14}$ Segue-se aqui de perto o enquadramento breve da tributação da poupança fornecido por Yoo e Serres (Yoo, Kwang-Yeol, e Serres, Alain de, "Tax Treatment of Private Pension Savings in OCDE Countries», OECD Economic Studies n. ${ }^{3}$ 39, 2004/2, pp. 75 e ss.). Diferente da sistematização seguida em texto, é a sustentada por EDWARD WHITEHOUSE, que distingue entre os regimes nos quais o rendimento é tributado apenas quando se traduz em despesa, seja ela feita em consumo, seja em investimento - regimes TEE e EET -, e os regimes nos quais o rendimento é globalmente tributado, independentemente de com ele se realizar despesa - regimes TTE e ETT (Whitehouse, Edward, «Fonds de pension et mesures de incitation fiscale», Risques, n. ${ }^{\circ}$ 23, 1995, pp. 101-118). Uma vez que a tónica do texto é exactamente colocada na vantagem que o mero diferimento da tributação constitui para o contribuinte - vantagem, aliás, atribuída, na maioria dos Estados-Membros, às aplicações em regimes complementares da Segurança Social, por contraposição a aplicações noutros veículos de poupança -, não seria adequada a utilização de uma sistematização que agrega regimes que tributam todo o rendimento no presente (TEE) a regimes que diferem totalmente a tributação desse rendimento (EET). 
a tributação (Taxed) na esfera do veículo. Por sua vez, a atribuição dos montantes ao beneficiário não patenteará um acréscimo patrimonial, não estando sujeita a tributação (Exempt). Nesta hipótese (TTE), todos os rendimentos aplicados e gerados pela poupança encontram-se, tal como o restante rendimento do contribuinte, sujeitos a tributação no momento em que surgem como acréscimo patrimonial.

Diferentemente, um sistema que conceda incentivos fiscais à poupança irá isentar de tributação a parcela de rendimento que for reservada para consumo futuro, sendo aplicada em veículos de poupança (regime expenditure tax). Como tal, um regime expenditure tax puro irá isentar os montantes aplicados em poupança $($ Exempt), bem como o acréscimo gerado, na esfera do veículo em causa, pela frutificação dos montantes aplicados (Exempt). Diferentemente, irá tributar os montantes em causa uma vez que estes sejam desafectados do veículo de poupança para serem destinados a consumo - ou seja, tributará o total da prestação atribuída pelo veículo de poupança ao beneficiário ( $T$ axed).

A este diferimento da tributação (EET) corresponde o benefício inerente à aplicação de um montante correspondente a rendimento bruto (não tributado) do contribuinte, e, por isso, necessariamente maior do que o montante correspondente ao mesmo rendimento, após incidência de tributação. Note-se, no entanto, que um esquema que não tribute os rendimentos ${ }^{15}$ gerados na esfera do veículo de poupança (TEE), e que tribute o rendimento aplicado em poupança à mesma taxa efectiva de tributação que um esquema EET poderá deixar, a final, o sujeito passivo com o mesmo rendimento disponível com que ficaria por aplicação daquele esquema EET. Basta, para o efeito, que a taxa de

${ }^{15}$ Não coarctando, assim, a sua aptidão para se incorporarem no capital aplicado, reproduzindo-se em progressão geométrica.

BOLETIM DE CIÊNCIAS ECONÓMICAS LI (2008), pp. 63-148 
rendibilidade da aplicação financeira seja igual à taxa de desconto aplicáve ${ }^{16}$.

Todas estas considerações valem para os regimes complementares que funcionam segundo o princípio puro da capitalização, constituindo como que uma forma qualificada ${ }^{17}$ de poupança, de que é exemplo a figura que a Directiva 2003/41/CE visa precipuamente regular (e que, entre nós, adopta a designação de fundo de pensões). Mesmo nos casos em que a prestação futuramente devida não seja determinada por critérios de pura capitalização, mas na sua modelação intervenham factores de aleatoriedade (pensa-se sobretudo nos seguros de $v^{1} \mathrm{da}^{18}$ ), o diferimento da tributação

${ }^{16}$ Isto é, que a relação entre o rendimento gerado no período e o capital aplicado seja igual à taxa de desconto aplicável. A taxa de desconto corresponde à remuneração da renúncia actual ao consumo, permitindo encontrar o preço actual do consumo futuro (preço intertemporal). Pelo que esta taxa corresponde, no fundo, à taxa de juro vigente no mercado $(j)$, e aquele preço intertemporal a $1 /(1-j)$. Este preço intertemporal será, pois, superior ao preço do consumo no futuro, uma vez que o segundo se encontra já deduzido do valor que traduz a renúncia ao consumo presente - o que vale por dizer que o preço do consumo no futuro é menor do que o correspondente preço intertemporal, uma vez que os consumidores não se dispõem a pagar um preço tão elevado por um bem que acarrete, para eles, a renúncia ao consumo actual. Para uma explicação exemplificada dos conceitos ver Burda, Michael, e Wyplosz, Charles, Macroeconomics, A European Text [sic], Oxford University Press, 1993, pp. 44 e ss.

${ }_{17}$ Com efeito, tal como os veículos que servem puras finalidades de poupança, os veículos que servem finalidades de previdência surgem pré-ordenados à rentabilização de entregas de capital, materializadas em contribuições efectuadas por um subscritor. Porém, no caso dos veículos que servem finalidades de previdência, só haverá, tendencialmente, lugar ao pagamento de qualquer soma ao beneficiário quando ocorram determinadas contingências tipificadas, correspondentes a riscos sociais.

${ }^{18}$ Mas não só: também os regimes financiados por um sistema pay-as-you-go, ou de repartição, estão expostos a imponderáveis atinentes às 
continuará a mostrar-se, como bem o apontou o Comité Económico e Social ${ }^{19}$, intrinsecamente mais equitativo, uma vez que a tributação incide sobre a prestação efectivamente recebida, e não sobre as contribuições efectuadas. Ora, e de iguais contribuições poderão resultar prestações diferentes para os diversos beneficiários, em função, por exemplo, da sua longevidade. Por outro lado, caso haja um diferimento total da tributação para o momento do pagamento da prestação, o beneficiário terá a oportunidade de pagar os impostos devidos com base no rendimento gerado no esquema de poupança.

$\mathrm{Na}$ prática, além do mais, à natural preferência dos indivíduos pelo pagamento de menos impostos no presente ${ }^{20}$, junta-se a aplicação, aos rendimentos gerados pela poupança, das taxas marginais de tributação que valem para os rendimentos de capitais, e que são substancialmente mais baixas

variações no número de contribuintes para o sistema, que geram um considerável grau de incerteza quanto ao an e ao quantum das pensões que o sistema poderá pagar.

${ }^{19}$ Parecer do Comité Económico e Social sobre a Comunicação da Comissão ao Conselho, ao Parlamento Europeu e ao Comité Económico e Social: Eliminação dos obstáculos fiscais aos regimes de pensões profissionais transfronteiras, in JO C036, de 08.02.2002 pp. 0053 -0058 .

${ }^{20}$ Já que o pagamento de impostos no presente implica a diminuição actual do rendimento disponível dos sujeitos, privando-os, desde logo, quer de consumo presente, quer da possibilidade de aplicação dos montantes em investimento. Quanto a esta privação da possibilidade de investimento actual, pode dizer-se, embora a categoria seja utilizada em relação à teoria da escolha, que o contribuinte privado de investir por força do pagamento do imposto incorre também num custo de oportunidade, correspondente ao valor da mais valorizada das alternativas ou oportunidades que deixam de ser possíveis por força do pagamento do imposto (seguimos de perto a definição dada por JAMES M. BUCHANAN Buchanan, James M., "Opportunity cost», The New Palgrave - A Dictionary of Economics, Vol. 3, 1998). 
do que as taxas marginais de tributação que terão incidido sobre os rendimentos aplicados na poupança - as taxas que valem para os rendimentos do trabalho ou da prestação de serviços ${ }^{21}$.

Assim se compreende que, na tributação dos rendimentos aplicados e gerados por regimes de pensão complementares, muitos Estados optem por um sistema EET, permitindo aos trabalhadores deduzir ao respectivo rendimento tributável os montantes que entreguem a regimes complementares, prevendo uma isenção para o período de formação do rendimento, e tributando apenas aquando do pagamento do rendimento de pensões. Outra forma, menos pura, desta "tributação invertida" (reversal rule) consiste na isenção/dedução do montante correspondente a contribuições, combinada com a tributação dos rendimentos gerados por frutificação das contribuições, e com a tributação, a final, das pensões pagas (ETT).

Este é, na verdade, o caso geral entre os Estados-Membros da União Europeia, encontrando-se em linha com as directrizes europeias relativas à sustentabilidade dos sistemas de pensões dos Estados-Membros. Por um lado, o incentivo fiscal materializado, como se viu, no diferimento da tributação, fomenta a previdência privada. Por outro lado, este esquema de tributação conduz à redução das receitas fiscais actuais em troca de receitas fiscais futuras, no momento em que o coeficiente de dependência demográfica será previsivelmente muito mais desfavorável ${ }^{22}$.

${ }^{21}$ Permitindo, assim, esta tributação diferida a geração de um maior rendimento líquido - ou seja, correspondendo tk à taxa marginal de tributação do rendimentos de capitais, $t l$ à taxa marginal de tributação dos rendimentos do trabalho e $j$ à taxa de rendibilidade dos capitais, se $t k<t l$, então $r(1-t l)^{\star} j<r^{\star} j(1-t k)$.

${ }^{22}$ Ver neste sentido o Parecer do Comité Económico e Social sobre a Comunicação da Comissão ao Conselho, ao Parlamento Europeu 
Lembre-se, no entanto, que, tanto ou mais decisivo do que um benefício assente sobretudo num diferimento da tributação, poderá será um benefício que assente numa isenção definitiva, total ou parcial, dos rendimentos em causa, ou num desagravamento da taxa de tributação aplicável. Assim, Estados há que, não abandonando uma política de incentivo à contratação de esquemas complementares de reforma, adoptam estruturas de tributação TTE/ $\mathrm{TEE}^{23}$.

\subsection{Problemas levantados}

A tributação através de um sistema EET, ou ETT, de rendimentos aplicados em ou gerados por regimes complementares de reforma pressupõe a articulação entre diferentes períodos de tributação. Com efeito - e como acima se viu a tributação de determinado acréscimo patrimonial não é feita no período em que o correspondente rendimento é gerado, mas apenas num período de tributação futuro. Assiste-se aqui, no fundo, a uma aplicação restrita aos rendimentos descritos e, por isso, meramente sectorial, do con-

e ao Comité Económico e Social: Eliminação dos obstáculos fiscais aos regimes de pensões profissionais transfronteiras, anteriormente citado, e o Parecer do Comité Económico e Social sobre a Comunicação da Comissão - Para um mercado único dos regimes complementares de reforma - Resultados das consultas sobre o Livro Verde sobre os regimes complementares de reforma no Mercado Único, 1999/C 368/18, JO C368, de 20.12.1999, p. 57.

${ }^{23}$ Nesta linha, a Alemanha, que adopta tendencialmente o princípio da comprehensive income taxation. Sobre a transição deste sistema alemão de tributação dos rendimentos de pensões para os moldes da tributação diferida, ver FEHR, Hans, e Jess, Heinrich, «Who Benefits from the Reform of Pension Taxation in Germany?», Fiscal Studies, 28, 1, 2007, pp. 73 e ss. 
ceito de lifetime income tax ${ }^{24}$, aferindo-se da capacidade contributiva do sujeito através de rendimento gerado em mais do que um período.

Os problemas em análise prendem-se exactamente com a transposição de um destes sistemas de tributação para uma economia integrada num mercado comum ou interno, em que se pretende assegurar uma livre circulação de factores de produção, pelo "afastamento não só das barreiras alfandegárias ao comércio como também pelo afastamento das 'barreiras não visíveis" "25 às trocas e à concorrência.

Em matéria de impostos sobre o rendimento e o capital, confrontam-se fundamentalmente ${ }^{26}$ dois tipos de pretensões

${ }^{24}$ Neste sentido, Stevens, L., "Worrying about pension problems in the European Union", in EC Tax Review, 2, 2003, pp. 66 e ss. A vigência deste conceito enquanto critério geral de tributação em sede de impostos sobre o rendimento das pessoas singulares, em oposição ao critério geralmente vigente de annual income tax, é advogada por alguma doutrina norte-americana (assim, Martin, no Canadá, e Schlunk, nos E.U.A.). Para uma proposta (em moldes extremados e completamente desfasados de realidades como a portuguesa, que de modo nenhum se pode acompanhar) de implementação de variante do lifetime income concept enquanto critério geral de tributação do rendimento pessoal, ver Schlunk, Herwig J., "A lifetime income tax», New York University Law and Economics Research Paper Series, Working Paper N. ${ }^{\circ}$ 02-06, 2005.

25 Sobre o alcance do conceito de mercado único ou mercado interno, vd. por todos Porto, Manuel Carlos Lopes, Teoria de Integração e Políticas Comunitárias, Almedina, 2001, maxime pp. 213 e ss., e 223 e ss.

26 De entre as economias mais desenvolvidas, são excepção os E.U.A. e as Filipinas, que, em matéria de impostos sobre o rendimento, aplicam também a conexão pessoal da nacionalidade. Sobre todo este ponto cfr., por todos, Xavier, Alberto, Direito Tributário Internacional, $2^{\text {a }}$ Edição, Almedina, 2007, maxime pp. 4-30, 226-232 e 261-296. Quanto à justificação material para uma pouca relevância actual do critério da nacionalidade, enquanto delimitador do poder tributário de um Estado, vd. sobretudo quanto aí se diz na p. 263: “O princípio da igualdade entre cidadãos e estrangeiros, quanto aos factos verificados no território 
tributárias: a pretensão do Estado da residência do sujeito passivo e a pretensão do Estado da fonte do rendimento.

Ao contrário de um critério puro de nacionalidade, o critério da residência ${ }^{27}$ releva ainda da soberania territorial do Estado, manifestada através de uma conexão subjectiva: o Estado considera as manifestações de capacidade contributiva dos sujeitos que residam no seu território. Assim, à aplicação de uma conexão residência corresponde tendencialmente uma obrigação tributária ilimitada: o Estado cobrará impostos sobre a totalidade do rendimento dos seus residentes, independentemente do local de obtenção dos mesmos (princípio do world-wide-income). Deste modo se compreende que este seja o Estado melhor colocado para ter em consideração a globalidade da situação pessoal do sujeito passivo reflectida na sua situação patrimonial ${ }^{28}$.

$\mathrm{O}$ critério da fonte ${ }^{29}$ releva directamente da soberania territorial do Estado, sustentando o poder de tributar os

de um dado Estado, decorre, na verdade, dos princípios da igualdade e da capacidade contributiva, que apenas consideram como fundamento legítimo de um desigual tratamento tributário, a desigualdade de capacidade económica, com total abstracção de outros critérios pessoais, considerados arbitrários.".

${ }^{27}$ Este é geralmente um conceito autónomo, modelado por cada ordenamento jurídico fiscal tendo em conta a teleologia deste sector. Para uma análise de várias possibilidades de densificação do mesmo, e sua contraposição ao conceito de domicílio tributário, cfr. XAvier, Alberto, Direito Tributário Internacional, 2 a Edição, Almedina, 2007, pp 280 e ss..

${ }^{28}$ Ver sobre o ponto, Ribeiro, José Joaquim Teixeira, Lições de Finanças Públicas, Coimbra Editora, 1995, maxime pp. 291 a 293.

${ }^{29} \mathrm{O}$ conceito de fonte vale tanto num sentido mais económico, de fonte de produção do rendimento, como, mais modernamente, num sentido financeiro de local de realização ou pagamento do rendimento. As normas de tributação procedem, muitas vezes, à concretização destes critérios através do recurso a ficções jurídicas; e servem-se, normalmente, de um ou de outro dos critérios, em função do tipo de rendimento em 
rendimentos produzidos por não residentes no território (conexão objectiva). Assim se compreende que "os mesmos sistemas fiscais tendam a impor uma obrigação tributária limitada (beschränkte Steuerpflicht) aos não residentes, submetendo a imposto apenas os rendimentos decorrentes de fontes localizadas no seu território." 30 .

Ora, um Estado que adopte um critério de tributação EET ou ETT não tributará, no momento do respectivo acréscimo, os fluxos patrimoniais a partir dos quais os seus residentes ${ }^{31}$ constituam o direito a receber uma pensão de reforma complementar. Esse Estado diferirá a tributação desses fluxos patrimoniais para o momento em que o seu residente receber o rendimento em causa na forma de pensão.

Atenta a livre - e crescente - mobilidade do factor trabalho ${ }^{32}$, é bom de ver que um sujeito poderá deixar de ser residente num Estado durante o processo de constituição ou de pagamento de uma pensão complementar. E, assim,

causa (cfr. XAviER, Alberto, Direito Tributário Internacional, $2^{\mathrm{a}}$ Edição, Almedina, 2007, p. 297 e ss.).

30 Xavier, Alberto, Direito Tributário Internacional, $2^{\mathrm{a}}$ Edição, Almedina, 2007, p. 231.

31 Os Estados que optem pelo diferimento da tributação dos rendimentos tenderão a conceder este diferimento apenas a sujeitos passivos residentes, face aos quais os Estados detêm uma pretensão tributária ilimitada: por um lado, porque é esta pretensão ilimitada que permite aos Estados considerar a globalidade do rendimento do sujeito passivo, e tributá-la de acordo com caracteres pessoalizantes; por outro, porque apenas face a esta pretensão ilimitada podem os Estados esperar recuperar o todo ou parte dos montantes correspondentes à tributação de determinada espécie de rendimento (salário ou pagamento de serviços), que diferiu, através da tributação futura de rendimentos de outra espécie (pensões).

${ }^{32}$ Usamos o termo "trabalho" num sentido muito lato, que abrange tanto os prestadores de serviços, como os antigos trabalhadores (neste último aspecto, conformemente com a acepção comunitária dos beneficiários da liberdade de circulação de trabalhadores - cfr. infra, I. 3.2). 
obter o diferimento da tributação do fluxo patrimonial em causa, e não possuir já qualquer conexão com essa ordem jurídica ao tempo em que receber a pensão, que essa ordem jurídica consideraria tributável. Nos casos de concessão do benefício do diferimento, o Estado regista uma despesa fis$\mathrm{cal}^{33}$ durante o tempo de formação das pensões, que não logrará recuperar mediante a tributação do rendimento gerado a final. A perda de receita fiscal será muito significativa para os países exportadores de pensões em que os regimes complementares de reforma gozem de forte implantação ${ }^{34}$. Note-se desde já que este problema não se coloca nos Estados com esquemas TTE/TEE, em sede geral.

${ }^{33}$ Não se desconhece que o Estado só registará, durante o tempo de diferimento da tributação, uma despesa fiscal em sentido técnico, ou seja, assimilável a uma despesa directa dos entes públicos (cfr., por exemplo, art. $106^{\circ}$, n. ${ }^{\circ} 3$, al. g) da CRP), caso considere este diferimento um verdadeiro benefício fiscal, derrogatório do sistema de tributação regra. No entanto, mesmo quando o ordenamento em causa considere este diferimento de tributação como uma medida de desagravamento estrutural, entendendo que parcela do rendimento corrente aplicada na constituição de pensões complementares de reforma não constitui uma verdadeira manifestação de capacidade contributiva, se verificará, no momento em que a tributação dos montantes deveria ocorrer, uma "receita fiscal cessante". Essa perda aqui resultará de não se conseguir tributar a manifestação de capacidade contributiva apurável apenas a final, em virtude já não haver conexão com a relação jurídica que the está na base. Vd., quanto a esta matéria, Gomes, Nuno Sá, Teoria Geral dos Benefícios Fiscais, Cadernos de Ciência e Técnica Fiscal, n. ${ }^{\circ}$ 359, 360 e 362, Centro de Estudos Fiscais, 1991, passim; quanto à avaliação da despesa fiscal em que se traduz a atribuição de beneficios fiscais, vd. por todos Grupo de Trabalho criado por despacho de 1 de Maio do Ministro de Estado e das Finanças, Reavaliação dos Benefícios Fiscais Relatório do Grupo de Trabalho criado por despacho de 1 de Maio do Ministro de Estado e das Finanças, Cadernos de Ciência e Técnica Fiscal, n. ${ }^{\circ}$ 198, Coimbra, Almedina, 2005, maxime pp. 58 a 110.

${ }^{34}$ Assim, Stevens, L., "Worrying about pension problems in the European Union”, EC Tax Review, 2, 2003, pp. 66 e ss. 
Restaria, ainda assim, aos Estados a hipótese de tributar o rendimento pago a final, a título de Estado da fonte do rendimento. Para tal, seria, no entanto, necessário que os Estados, ao tempo do pagamento da pensão, conseguissem impor os seus comandos a qualquer dos sujeitos da relação jurídica geradora do quid tributável. Uma vez que aqui analisamos a hipótese em que o beneficiário da pensão não se encontra já ligado ao Estado em causa, o tributo poderia ser exigido à entidade pagadora da pensão. Simplesmente, a instituição em causa pode, ela própria, não ter qualquer contacto com a ordem jurídica em causa. Com efeito, o subscritor pode ter celebrado o contrato com uma instituição num Estado diverso daquele em que residisse ao tempo da prestação do trabalho ${ }^{35}$. Ou a própria instituição pode, ao abrigo da liberdade de prestação de serviços (arts. 49. ${ }^{\circ}$ e ss. TCE $)^{36}$, ter oferecido os seus serviços à contratação num Estado-Membro em que não estivesse estabelecida.

Num caso, ou noutro, ao tempo do pagamento da pensão, o Estado que permitiu ("suportou”) as deduções não terá já qualquer contacto com a relação jurídica, não logrando tributá-la. Como defesa antecipada face à possibilidade de o sujeito passivo deixar de residir no território antes do ou durante o pagamento da pensão, um Estados que adopte, em tese geral, regimes EET ou ETT, pode excepcionar deste âmbito os casos de contratação com instituição de pensões não

${ }^{35}$ Desde logo, por trabalhar num Estado diferente do da residência.

${ }^{36}$ Em sede de direito derivado, as concretizações deste princípio, no âmbito em apreço, encontram-se nos arts. $41 .^{\circ}$ e $42 .^{\circ}$ da Directiva 2002/83/CE do Parlamento Europeu e do Conselho, de 5 de Novembro de 2002, relativa aos seguros de vida, (JO L345 de 19.12.2002, p. 1-51) e no art. 20. ${ }^{\circ}$ da Directiva 2003/41/CE do Parlamento Europeu e do Conselho, de 3 de Junho de 2003, relativa às actividades e à supervisão das instituições de realização de planos de pensões profissionais, citada acima. 
estabelecida no território ${ }^{37}$. Assim, nega aos rendimentos aplicados em contratos com instituições não estabelecidas o benefício do diferimento da tributação, não permitindo a dedução das contribuições efectuadas. Em detrimento, portanto, das instituições não estabelecidas, bem como dos subscritores que com elas contratem - o que os pode especialmente prejudicar quando a escolha da instituição se deva ao facto de trabalharem ou terem trabalhado noutro Estado-Membro.

As problemáticas descritas dizem respeito ao funcionamento dos regimes EET e ETT, em especial. Porém, da mera convivência de Estados que prevejam regimes de tributação diferentes podem resultar efeitos perversos ao nível da tributação dos rendimentos em causa: assim, a migração de um subscritor de um Estado EET para um Estado TEE trar-lhe-á o benefício indevido da dupla não tributação. Por outro lado, a migração do subscritor de um Estado TTE para um Estado EET sujeitá-lo-á a dupla tributação dos rendimentos em causa. E igual dupla tributação poderá ser causada pela transferência de montantes alimentados por contribuições tributadas (feitas sob uma ordem TEE, por exemplo) para Estados que igualmente tributem as contribuições efectuadas (TTE/TEE) - uma vez aquela transferência constituirá, na óptica do Estado ad quem, uma contribuição no valor do montante transferido.

${ }^{37}$ Com efeito, a tendencial consagração de sistemas de diferimento da tributação acarreta a perda de receitas fiscais por parte dos países exportadores de pensões - os países cuja população trabalhadora, por um ou outro motivo, tenda a abandonar o território durante ou após a respectiva vida activa. Logo, este país tenderá a desencorajar a mobilidade (onerando-a fiscalmente) de trabalhadores com direitos em formação. Assim, Stevens, L., "Worrying about pension problems in the European Union», EC Tax Review, 2, 2003, pp. 66 e ss. 
O quantum dessa dupla tributação dependerá da intensidade da tributação a que cada um dos ordenamentos competentes sujeite, em concreto, os rendimentos em causa. Verificando-se mesmo, in limine, a possibilidade de uma dupla tributação total, ou de total uma elisão da tributação.

\subsection{Conclusões}

A problemática descrita retrata a feição que assume, nesta sede em particular, um traço que predica o mercado comum: o da coexistência de um grau superior de integração económica, concretizado na livre circulação não apenas de mercadorias, mas dos diversos factores de produção (Parte I, 3.), com a subsistência da um grau de harmonização muito modesto em matéria de impostos sobre o rendimento (Parte II, 1.).

\section{O impacto sobre as liberdades comunitárias}

\subsection{O problema da criação de discriminações contrárias ao artigo $12 .^{\circ} \mathrm{TCE}$}

Em primeiro lugar, cumpre dizer que a apreciação dos efeitos sobre as liberdades comunitárias fundamentais derivados da falta de harmonização fiscal tem cabido sobretudo ao TJCE. Essa actuação tem ocorrido em sede de reenvio prejudicial, ou de acções por incumprimento, dirigindo-se quase invariavelmente $^{38}$ a analisar a compatibilidade com os

${ }^{38}$ Com uma excepção, correspondente ao regime anteriormente vigente na Suécia, onde o regime geral ETT seria, no caso de aplicação 
Tratados de normas fiscais de Estados-Membros similares às que referenciamos no final do ponto anterior. Isto é, de normas fiscais pelas quais um Estado-Membro que consagra, em sede geral, um regime de tributação EET ou ETT subtrai à aplicação desse regime geral o rendimento associado a regimes de pensões complementares que comportem certos elementos de extraterritorialidade ${ }^{39} 40$.

Como tal, coloca-se de antemão a questão da compatibilidade dessas normas tributárias nacionais com o princípio geral de proibição da discriminação constante do art. $12{ }^{\circ}$ do TCE. Literalmente, este princípio proíbe qualquer discriminação em razão da nacionalidade. Faz-se notar que, assim literalmente compreendido, de pouco préstimo seria em

em instituições não estabelecidas, não só alterado para TTE, como implicaria a aplicação de taxa mais elevada aos rendimentos de capital gerados na esfera do esquema de previdência. Este ponto veio posteriormente a ser contemplado em procedimento por infracção instaurado pela Comissão, e foi corrigido pelo Estado Sueco, não tendo o Tribunal de Justiça chegado a pronunciar-se sobre a questão.

39 A saber, até à data: o Acórdão de 28 Janeiro de 1992, Comissão c. Bélgica (C-300/90, Colect. 1992, p. I-00305), o Acórdão de 28 de Janeiro de 1992, Bachmann (C-204/90, Colect. 1992, p. I-00249), o Acórdão de 11 de Agosto de 1995, Wielockx (C-80/94, Colect. 1995, p. I-02493), o Acórdão de 28 de Abril de 1998, Safir (C-118/96, Colect. p. I-1897, n. ${ }^{\circ}$ 30), o Acórdão de 3 de Outubro de 2002, Danner (C-136/00, Colect. 2002 p. I-08147), o Acórdão de 26 de Junho de 2003, Skandia (C-422/01, Colect. 2003, p. I-06817), e o Acórdão de 30 de Janeiro de 2007, Comissão c. Dinamarca (C-150/04, ainda não publicado em Colectânea). Esta jurisprudência será doravante citada pelo nome do caso.

${ }^{40}$ Já fora de tempo útil para que pudesse ser incluído na estrutura do presente trabalho, foi entretanto proferido pelo TJCE o Acórdão de 5 de Julho de 2007, Comissão c. Bélgica (C-522/04, ainda não publicado em Colectânea). Trata-se de jurisprudência que constitui um prolongamento natural daquela que é citada em texto, e em relação à qual se farão, em nota, as pertinentes referências. 
sede tributária, em que - como se assinalou - o critério da nacionalidade não tem um relevo específico.

Coube ao Advogado-Geral Tesauro, através de conclusões apresentadas no caso Safir ${ }^{41}$, transpor para esta sede a jurisprudência constante ${ }^{42}$ do Tribunal de Justiça, segundo a qual esta disposição só deve ser aplicada de modo autónomo a situações face às quais o Tratado não preveja norma específica de não discriminação. As normas sobre livre prestação de serviços e liberdade de circulação de capitais são normas que concretizam este princípio, valendo aqui como normas especiais. Também assim se pronunciou o Advogado-Geral LÉGER, em conclusões apresentadas no caso Skandia ${ }^{43}$, e no mesmo sentido foi o acórdão proferido a final ${ }^{44}$.

Pelo que as potencialidades interpretativas deste artigo não chegariam a ser exploradas nesta sede.

\subsection{A livre circulação de trabalhadores}

A livre circulação de trabalhadores encontra-se prevista no art. 39. ${ }^{\circ}$ do TCE e confere aos respectivos beneficiários, desde logo, os direitos de resposta, deslocação, residência e permanência que no n. ${ }^{\circ} 3$ desse artigo se elencam. Desta

${ }^{41}$ Conclusões do Advogado-Geral Tesauro, apresentadas a 23 de Setembro de 1997 (Colect. 1998, p. I-01897).

42 O Advogado-Geral cita os acórdãos de 30 de Maio de 1989, Comissão/Grécia (305/87, Colect., p. 1461, n. 13) e de 14 de Julho de 1994, Peralta (C-379/92, Colect., p. I-3453, n.18).

${ }^{43}$ Conclusões do Advogado-Geral LÉGer, apresentadas a 3 de Abril de 2003 (Colect. 2003, p. I-06817).

${ }^{44}$ No caso Danner, em que a questão da aplicação deste art. $12{ }^{\circ}$ foi igualmente levantada, a respectiva apreciação foi prejudicada por se decidir pela incompatibilidade das disposições nacionais com a livre prestação de serviços. 
liberdade, que se configura como um verdadeiro "direito fundamental" (acórdão Heylens ${ }^{45}$ ), beneficiam os sujeitos humanos nacionais de Estados-Membros que exerceram, pretendem exercer ou exercem uma actividade económica assalariada ${ }^{46}$.

Ora, as liberdades de residência ou permanência do trabalhador podem, na prática, ser restringidas pelos custos fiscais implicados, em sede de regimes complementares de reforma, pela deslocação para outra ordem jurídica. Pense-se, por exemplo, na hipótese de, em virtude de uma deslocação permanente, o trabalhador assim incorrer em dupla tributação; ou na hipótese de, por o trabalhador pretender continuar a contribuir para uma instituição de pensões estrangeira, não beneficiar, no Estado-Membro de acolhimento, de direito à dedução dos prémios pagos.

A última hipótese referida retrata um dos citados casos de aplicação de normas especiais por regimes EET/ETT, tendo sido, nesta sede, objecto de análise pela jurisprudência comunitária. Aí se considerou, aliás, que, por serem normalmente os nacionais de outro Estado-Membro que terão concluído um contrato de seguro com uma instituição estabelecida noutro Estado-Membro, as normas internas especiais discriminariam indirectamente contra estes (acórdãos Comissão c. Bélgica e Bachmann) ${ }^{47} 48$.

45 Acórdão de 15 de Outubro de 1987, Union Nationale des entretâ1neurs et cadres techniques professionnels du football (Unectef) c. Georges Heylens e outros, 222/86 (Colect. 1987, pp. 4097 e ss.).

${ }^{46}$ Cfr. Gorjão-Henriques, Miguel, Direito Comunitário, Almedina, 2007, pp. 441-443, e jurisprudência que aí se cita.

${ }^{47}$ Num caso, como noutro, estava em causa o condicionamento da dedução das contribuições para seguros de saúde, invalidade, vida ou reforma ao facto de o pagamento dos montantes ser feito 'na Bélgica' hoc sensu, a seguradoras estabelecidas na Bélgica. Quando não tivesse 


\subsection{O direito de estabelecimento}

O direito de estabelecimento encontra tutela no art. 43. ${ }^{\circ}$ do TCE e, "tal como entendido ao longo da construção comunitária, permite o exercício (por pessoa singular ou colectiva) [no território de outro Estado-Membro] de actividades não assalariadas que apresentem características de estabilidade e permanência." ${ }^{49}$. Vale aqui o que se disse acima quanto aos obstáculos colocados à livre circulação de trabalhadores por via da fiscalidade dos regimes complementares de pensões: o estabelecimento noutro Estado-Membro pode implicar dupla tributação, ou o cercear das possibilidades de dedução das contribuições efectuadas.

A invocabilidade do direito de estabelecimento contra normas tributárias internas aplicáveis a regimes complementares de reforma foi especificamente analisada no acórdão Wielockx. Estava em causa a aplicação de um regime holandês aplicável aos trabalhadores independentes, que lhes permitia a constituição de uma reserva para fins de previdên$\mathrm{cia}^{50}$, adentro dos proveitos gerados pela sua actividade, com

havido lugar à dedução das contribuições efectuadas, os montantes pagos ao abrigo do contrato de seguro não seriam considerados rendimento tributável.

${ }^{48}$ Numa linha similar, a Advogada-Geral Stix-HAckL, em Conclusões apresentadas no caso Comissão c. Dinamarca, em 1 de Junho de 2006, e ainda não publicadas em Colectânea. Nestas, a Advogada alega que a regulamentação afecta sobretudo trabalhadores migrantes de outros Estados-Membros, por conta de outrem e por conta própria, que têm que aceitar um regime fiscal menos vantajoso se quiserem conservar o seu regime de pensões estrangeiro.

49 In Gorjão-Henriques, Miguel, Direito Comunitário, Almedina, 2007, p. 452.

${ }^{50}$ Note-se que o regime em causa é particularmente favorável, uma vez que permite que esta reserva permaneça no património da empresa 
dedução ao rendimento tributável das somas afectas a esta reserva. Ora, a faculdade de dedução descrita não era permitida a beneficiários não residentes na Holanda, o que o Tribunal de Justiça veio considerar incompatível com a liberdade de estabelecimento.

Esta questão comporta atinências com outros casos analisados pela jurisprudência comunitária, em que se questiona a tradicional repartição de poderes tributários entre o Estado da residência do contribuinte e o Estado da fonte do rendimento ${ }^{51}$.

Conforme acima se observou, ao Estado da residência do contribuinte cabe tipicamente uma pretensão tributária sobre o rendimento global do sujeito passivo, sendo, assim, este o ordenamento melhor posicionado para proceder à pessoalização da tributação. Assim, a este Estado - e não ao Estado da fonte do rendimento (Estado holandês, onde Wielockx trabalhava numa clínica) - caberia ter em conta eventuais deduções ao rendimento tributável, realizadas para acorrer a encargos pessoais, na medida em que o respectivo ordenamento as previsse. $\mathrm{Na}$ jurisprudência comunitária

e, simultaneamente, confere o direito à dedução das somas que lhe são afectas. O beneficiário adquire direito a desafectar as somas aos 65 anos, sendo as mesmas então tributadas enquanto rendimento.

51 Já o Advogado-Geral LÉGER, nas Conclusões apresentadas no processo, a 31 de Maio de 1995 (Colect. 1995, p. I-02493), louvando-se na jurisprudência do acórdão Schumacker (Acórdão de 14 de Fevereiro de 1995, Schumacker (C-279/93, Colect. 1995, p. I-225), sustenta que uma discriminação fundada na residência não é, em si, contrária ao Direito Comunitário. A capacidade contributiva do não residente pode ser mais cumpridamente tida em consideração pelo centro dos interesses pessoais e patrimoniais do sujeito. Porém, se (e só se) um sujeito auferir a totalidade ou quase totalidade dos rendimentos no Estado onde tem o seu emprego, encontrar-se-á numa situação fiscal idêntica à dos residentes desse Estado. Como tal, nesse caso, deve considerar-se discriminado. 
$\left(\right.$ Schumacker $\left.^{52}\right)$ têm, porém, surgido casos em que se questiona a justeza dessa alocação. Trata-se de casos - como o citado - em que o sujeito aufere a totalidade ou a quase totalidade dos seus rendimentos tributáveis junto do Estado da fonte destes rendimentos, tendo, por isso, uma posição materialmente muito próxima da de um residente ${ }^{53}$.

$\mathrm{O}$ acórdão produzido a final sustentaria, tendo em consideração essa jurisprudência, e em linha com as Conclusões apresentadas pelo Advogado-Geral LÉGER ${ }^{54}$, que embora uma discriminação fundada na residência não seja, em si, contrária ao Direito Comunitário, um trabalhador que apenas receba rendimentos no Estado em que exerce a sua actividade está numa situação comparável à de um residente desse Estado - apresenta ao Fisco a mesma base tributária que um residente que ocupe o mesmo posto. Nessa medida, o tratamento diferenciado desse trabalhador deve ser considerado discriminatório - aliás, a ser de outro modo, poderia colocar-se, na situação, um problema de conflito negativo

52 Acórdão de 14 de Fevereiro de 1995, Schumacker (C-279/93, Colect. 1995, p. I-225).

53 Apesar da aparente bondade material da doutrina vertida nos Acórdãos Schumacker e Wielockx, a imprecisão e o casuísmo que acompanham a sua aplicação não deixaram de suscitar crítica, pela incerteza jurídica que geram. Desde logo, critica-se a falta de definição clara de qual o ordenamento afinal competente para computar o rendimento global do sujeito passivo, para que se possa determinar onde este é, na sua maior parte, auferido. Quanto a estas questões, cfr. CARRERo, José Manuel Calderón, e Jiménez, Adolfo Martín, «La armonización jurisprudencial de la imposición directa: las implicaciones fiscales del principio comunitário de no discriminación relación con las libertates básicas comunitarias», Manual de Fiscalidad Internacional, Instituto de Estudios Fiscales, 2004, pp. 1196 e ss.

54 Conclusões do Advogado-Geral Léger, apresentadas a 31 de Maio de 1995 (Colect. 1995, p. I-02493). No processo, estas foram seguidas muito de perto pelo Acórdão proferido. 
de competências face à consideração da situação pessoal e familiar do contribuinte ${ }^{55}$.

${ }^{55}$ Como o nota Patrícia Noiret da Cunha, o Tribunal de Justiça aceitou (bem), nesta sede, a qualificação conferida pelo Estado da fonte à dedução que previa - a de dedução pessoal. Dada a forte ligação da dedução em causa ao património da empresa do profissional liberal, esta parecia, porém, mais próxima de uma "dedução aplicável objectivamente a um determinado tipo de rendimento". Caso assim a qualificasse o Estado da fonte, não haveria que convocar a doutrina Schumacker, devendo o Estado da fonte permitir a dedução, sem mais (CunHA, Patrícia Noiret da, A tributação directa na jurisprudência do Tribunal de Justiça, Coimbra Editora, 2006, pp. 176-177).

56 Apesar das críticas dirigidas contra o entendimento sustentado pelos Acórdãos Schumacker e Wielockx, é certo que a doutrina não logrou ainda erigir um critério alternativo, válido e seguro, para proceder à alocação do poder tributário entre o Estado da residência e o Estado da fonte (quanto aos vários critérios propostos, e à sua falência, cfr. CARRERo, José Manuel Calderón, e JimÉnez, Adolfo Martín, «La armonización jurisprudencial de la imposición directa: las implicaciones fiscales del principio comunitário de no discriminación relación con las libertates básicas comunitarias», Manual de Fiscalidad Internacional, Instituto de Estudios Fiscales, 2004, pp. 1211 e ss.). Por outro lado, merece a nossa rejeição um critério como o proposto por DenNis Weber (WeBER, Dennis, "In Search of a (New) Equilibrium Between tax sovereignity and the Freedom of Movement Within the EC", Intertax, 12, vol. 34, 2006). DenNis WeBer parte do que designa por per-country approach (por contraposição a uma overall approach), segundo a qual apenas existe uma restrição ilegítima da liberdade de circulação quando esta é gerada pela legislação de um único Estado-membro. Se, para descortinar a limitação à liberdade fundamental, houver que considerar a legislação aplicável em mais do que um Estado-Membro, aí já não se configurará uma restrição ilegítima, mas um mero resultado da convivência, lado a lado, de diferentes soberanias fiscais. DeNNIS WeBER considera, assim, que a discriminação é um fenómeno exclusivamente inerente à ordem jurídica de um único Estado-Membro. Porém, leva a sua lógica de desconsideração das ordens jurídico-fiscais adjacentes até às últimas consequências: segundo o A., a partir do momento em que o Estado decidir exercer a sua soberania fiscal face a um determinado rendimento, não lhe poderá dar tratamento 


\subsection{A livre prestação de serviços}

Trata-se de uma liberdade residual face às liberdades fundamentais anteriormente descritas, que permite a realização, com carácter temporário e independente, pelo nacional de um Estado-Membro, de prestações remuneradas no território de outros Estados-Membros, nas mesmas condições que esses Estados impõem aos seus próprios nacionais.

A jurisprudência comunitária que se tem debruçado sobre esta matéria em particular tem apreciado disposições dos Estados-Membros de que são exemplo as referidas acima: normas internas que, em Estados EET ou ETT, excluem do benefício geral da dedução as contribuições efectuadas junto de instituições de pensões não estabelecidas no Estado-Membro. Assim, nos acórdãos Comissão c. Bélgica e Bachmann, o Tribunal de Justiça entendeu que as disposições que exijam o estabelecimento num Estado Membro para que se bene-

diferente do conferido aos rendimentos dos seus residentes. Assim, as próprias deduções pessoais deverão ser aplicáveis por inteiro (isto é, e diferentemente do defendido por WATTEL, sem qualquer pró-ratização) ao rendimento auferido por não residente.

Trata-se de entendimento que não se pode acompanhar. Em primeiro lugar, por ser impraticável num espaço onde os sistemas tributários se regem por um figurino (descrito acima) correspondente ao assumido pela CMOCDE, no qual há um Estado que se erige como sede da tributação, e avalia a situação pessoal do sujeito reflectida na sua situação patrimonial. A construção proposta levaria, assim, à duplicação de deduções. Por outro lado, e num plano mais abstracto, não parece viável substituir a concepção que assenta na eleição de um Estado-sede da tributação, e competente para a pessoalização tributária - desde logo, porque há deduções pessoalizantes que não correspondem a despesas efectuadas (pense-se na dedução de um determinado montante por dependente a cargo, como a prevista pelo nosso CIRS), não se vendo qual o Estado, que não seja aquele que se erige a sede da tributação do sujeito, que as tomaria a seu cargo. 
ficie de uma vantagem fiscal específica constituem uma restrição à livre prestação de serviços.

Por sua vez, o Advogado-Geral Tesauro, através das Conclusões apresentadas no caso Safir ${ }^{57}$, inaugurou, nesta sede, uma linha argumentativa fundada numa ideia de dissuasão à contratação. Assim, segundo o Advogado, o regime fiscal vigente em matéria de contribuições para instituições não estabelecidas ${ }^{58}$ criaria entraves à livre prestação de serviços, uma vez que, tornando mais onerosa ${ }^{59}$ a contra-

${ }^{57}$ Conclusões do Advogado-Geral Tesauro, apresentadas a 23 de Setembro de 1997 (Colect. 1998, p. I-01897).

${ }^{58}$ Estava em causa o regime sueco de tributação dos rendimentos ligados a seguros de vida, que se mostrava diferente em função de as seguradoras contratadas serem nacionais da Suécia, ou estarem estabelecidas neste país, ou de não o estarem. Caso se tratasse da celebração de um "seguro pensão" celebrado com uma seguradora sueca ou estabelecida na Suécia, a poupança recolhida pela seguradora seria tributada, em parte, com base no montante do património da seguradora e, noutra parte, com base no rendimento atribuído aos beneficiários a final. Ou seja, neste caso, as contribuições efectuadas pelo segurado seriam deduzidas do seu rendimento no momento da respectiva efectuação. Caso a seguradora não fosse nacional nem estivesse estabelecida em território sueco, a poupança aplicada nestes seguros de vida não estaria sujeita a imposto na esfera da seguradora, cujo património não seria tributado, mas na esfera dos segurados, que estariam sujeitos a imposto sobre os prémios pagos.

A racionalidade subjacente a esta diferença de regimes seria a da garantia da igualdade concorrencial entre seguradoras sujeitas e não sujeitas a imposto em território sueco. Tanto assim, que o imposto sobre os prémios pagos poderia ser suprimido ou reduzido se o segurado comprovasse que a seguradora estava sujeita, no Estado em que se encontrasse estabelecida, a um imposto sobre o rendimento análogo ao que onera as companhias estabelecidas na Suécia.

${ }^{59}$ Esta maior onerosidade resultaria desde logo, in casu, da imposição aos tomadores de seguros em instituições não estabelecidas das obrigações de inscrição e declaração do prémio num registo; por outro lado, por os prémios investidos não se encontrarem isentos, de o tomador ter que mobilizar, desde logo, a liquidez necessária ao pagamento do 
tação de esquemas com instituições não estabelecidas, seria apto a dissuadir a contratação de seguros com estas instituições. Esta linha argumentativa foi subscrita no acórdão Safir, e ainda nas Conclusões apresentadas pelo Advogado-Geral JACOBs no caso Danner ${ }^{60}$, e no acórdão proferido a final neste caso.

Também o Advogado-Geral LÉGER, nas Conclusões apresentadas no caso Skandia ${ }^{62}{ }^{63}$, sufragou esta posição. Integrou,

imposto. Ao que acresce que, sendo o seguro contratado com instituição não estabelecida, o resgate efectuado pouco tempo depois da contratação poderia ser mais oneroso do que um resgate de seguro contratado com instituição estabelecida. Em quarto lugar, a faculdade de dedução dos prémios pagos a instituições não estabelecidas exigiria aos contribuintes segurados o fornecimento de informações precisas sobre o regime de imposto sobre o rendimento a que a instituição estivesse sujeita no local do respectivo estabelecimento. Esta exigência poderia ser pesada para os segurados, e dissuadir as instituições que não quisessem fornecer essa informação de operar no Estado-Membro. Por último, verificar-se-ia uma falta de segurança jurídica quanto às possibilidades de dedução de prémios pagos a instituições estrangeiras, dada a oscilação nos entendimentos das autoridades suecas relativamente aos casos de possibilidade e ao quantum dessa dedução.

${ }^{60}$ Conclusões do Advogado-Geral JacoBs, apresentadas a 21 de Março de 2002 (Colect. 2002, p. I01847).

${ }^{61}$ Estava em causa o regime previsto na Finlândia para os prémios pagos ao abrigo de esquemas voluntários, nos termos do qual apenas beneficiariam de dedução integral os prémios correspondentes a contratos celebrados com seguradoras finlandesas, ou que dispusessem de estabelecimento estável em território finlandês, ou, em certas condições e apenas durante três anos, nos casos de transferência da residência de um sujeito para a Finlândia.

${ }^{62}$ Conclusões do Advogado-Geral Léger, apresentadas a 3 de Abril de 2003 (Colect. 2003, p. I-06817).

${ }^{63}$ Estavam em causa as disposições suecas que vedavam à entidade empregadora a dedução ao respectivo rendimento dos prémios pagos a seguradoras estabelecidas no estrangeiro, prevendo que, neste caso, a tributação ocorresse no momento do pagamento das contribuições. 
no entanto, estes argumentos na invocação do princípio da não-discriminação, materializado, em matéria a livre prestação de serviços, no art. $50 .^{\circ}$ do TCE. O Advogado considerou que se aplicavam regras diferentes a situações comparáveis, operando-se uma discriminação. Por outro lado, as regras aplicáveis aos casos de seguradoras não estabelecidas teriam como efeito tornar a prestação de serviços entre Estados-membros mais difícil do que a puramente interna face a um Estado-membro (Comissão c. França e Smits e Peerbooms ${ }^{64}$ ), dissuadindo da contratação com instituições não estabelecidas. No fundo, impunha-se às prestadoras uma condição de estabelecimento no território sueco - e esta exigência constituiria uma discriminação indirecta contrária à livre prestação de serviços, que não poderia ser aceite sem justificação.

A Advogada-Geral Stix-HackL, em Conclusões apresentadas no caso Comissão c. Dinamarca ${ }^{65}{ }^{66}$, perfilha os enten-

De acordo com as próprias autoridades suecas, este regime poderia ser, em algumas hipóteses, menos favorável à entidade empregadora do que o regime geral: se o pagamento dos montantes devidos ao abrigo do contrato de seguro ocorresse muito tempo depois do pagamento das quotizações, quando o montante dos pagamentos não fosse muito superior ao das quotizações pagas, um seguro subscrito no estrangeiro poderia ter consequências mais desfavoráveis, a nível de tributação, do que um seguro subscrito na Suécia. Diferentemente, o regime seria mais favorável do que o correspondente a um seguro subscrito na Suécia se o pagamento dos montantes devidos ao abrigo do contrato, e a correspondente dedução, ocorressem pouco tempo após o pagamento das contribuições, e o montante das somas pagas fosse sensivelmente superior ao das contribuições efectuadas. Para o trabalhador, as diferenças de regime seriam neutras.

${ }^{64}$ Acórdão de 12 de Julho de 2001, Smits e Peerbooms (C-157/99, Colect. p. I-5473, n. ${ }^{\circ}$ 58).

${ }^{65}$ Conclusões da Advogada-Geral StiX-HackL, apresentadas em 1 de Junho de 2006 (Colect. 2007, p. I-01163).

${ }^{66}$ De acordo com a legislação dinamarquesa há, para efeitos de tributação, uma distinção fundamental entre duas categorias de planos de pensões. 
dimentos anteriores, acrescentando apenas que a alegação da violação da liberdade de prestação de serviços pode ainda apoiar-se, na linha do que tem sido prosseguido pela Comissão, na afectação do regime harmonizado previsto para os seguros de vida, instituído pelas Directivas 92/96/ $\mathrm{CEE}^{67}$ e 2002/83/ $\mathrm{CEE}^{68}$.

Para a primeira das categorias, está previsto um regime de vantagem fiscal, que confere ao subscritor (entidade patronal ou próprio participante) o direito a deduzir o montante da contribuição. Por outro lado, os rendimentos correntes dos planos de pensões são tributados a uma taxa de $15 \%$. Os pagamentos recebidos ao abrigo de um plano destes são depois tributados na esfera do beneficiário, enquanto parte do rendimento pessoal, à taxa marginal aplicável, ou a uma taxa autónoma de $40 \%$, caso se trate de seguros de capital. Nesta categoria, reentram apenas os planos subscritos junto de instituições com sede ou estabelecimento na Dinamarca.

A segunda categoria diz respeito a planos de pensões que não conferem beneficios fiscais. Neste caso, as contribuições não são dedutíveis ao rendimento. Nesta categoria, reentram os planos subscritos junto de instituições sem sede nem estabelecimento na Dinamarca, em duas modalidades: uma primeira, atinente aos casos em que o subscritor era residente na Dinamarca ao tempo da subscrição, e uma segunda, atinente aos casos em que o subscritor não era, nesse tempo, residente na Dinamarca. No âmbito da primeira modalidade, os rendimentos correntes dos planos de pensões são tributados, enquanto rendimentos de capitais; por sua vez, os pagamentos recebidos pelo subscritor ao abrigo do plano de pensões estão isentos. No âmbito da segunda modalidade, os rendimentos correntes dos planos de pensões não estão sujeitos a tributação; por outro lado, os pagamentos recebidos ao abrigo do plano de pensões apenas estão sujeitos a tributação - sendo, então, integrados no rendimento pessoal do subscritor - se o subscritor tiver podido deduzir as suas contribuições, ou se estas tiverem estado excluídas da tributação.

${ }^{67}$ Directiva do Conselho, de 10 de Novembro de 1992, que estabelece a coordenação das disposições legislativas, regulamentares e administrativas relativas ao seguro directo vida e que altera as Directivas 79/267/CEE e 90/619/CEE (terceira directiva sobre o seguro de vida), (JO L 360, p.1).

${ }^{68}$ Directiva do Parlamento Europeu e do Conselho, de 5 de Novembro de 2002, relativa aos seguros de vida (JO L 345, p. 1). 
Quanto a este ponto, faz-se, por último, notar, que iguais possibilidades de dissuasão à contratação, por ocorrência de uma dupla tributação que encareça o serviço em causa, brotam do mero convívio de ordens jurídicas. Pense-se numa contribuição feita por um trabalhador residente num Estado TEE a uma instituição localizada noutro Estado, onde o trabalhador exerça actividade, em que valha um regime ETT, vindo a instituição a pagar a pensão ao trabalhador quando este, por se ter reformado, mude a residência para um Estado EET.

\subsection{A livre circulação de capitais}

Ao abrigo do TCE, são proibidas todas as restrições aos movimentos de capitais e aos pagamentos entre Estados-Membros ou entre Estados-Membros e Estados terceiros. Trata-se de liberdade que apenas colhe verdadeira autonomia relativamente aos movimentos de capitais e aos pagamentos correntes que lhes são inerentes. Com efeito, os pagamentos correntes destinados a remunerar qualquer dos factores abrangidos pelas restantes liberdades devem considerar-se abrangidos no âmbito destas mesmas liberdades ${ }^{69}$. Assim, é jurisprudência assente que apenas constituem movimentos de capital as transacções financeiras autónomas, enquanto "operações que têm essencialmente por objecto a colocação ou investimento do montante respectivo e não a remuneração de uma prestação.” (Luisi e Carbone ${ }^{70}$ ).

${ }^{69} \mathrm{Vd}$. por todos, no quadro prévio à revisão dos Tratados pelo Tratado de Amesterdão, CAmpos, João Mota de, Direito Comunitário - III Volume - O Ordenamento Económico, Fundação Calouste Gulbenkian, 1997, pp. 454 e ss.

70 Citado em Campos, João Mota de, Direito Comunitário - III Volume - O Ordenamento Económico, Fundação Calouste Gulbenkian, 1997, p. 459. 
Também quanto à matéria em análise se tem entendido que esta liberdade apenas deve ser invocada quando haja um obstáculo directo aos movimentos de capitais, e não um obstáculo in primis a outra liberdade, apenas de modo indirecto contendendo com aquela. Coube aos acórdãos Comissão c. Bélgica e Bachmann a transposição desse entendimento para este âmbito, sendo acompanhados pela casuística que posteriormente foi chamada a pronunciar-se sobre a questão ${ }^{71}$. Apenas a Advogada-Geral STIX-HAcKL apresenta uma nota dissonante nesta sede, conformando-se com a jurisprudência assente ${ }^{72}$, mas dando nota de que as «transferências em execução de contratos de seguros» e, em especial, os «prémios e prestações a título do seguro de vida» referidos na nomenclatura da Directiva $88 / 361 / \mathrm{CEE}^{73}$ enquanto movimentos de capitais, seriam dissuadidos pelas normas fiscais que tornariam estes prémios mais onerosos. Tendo em

${ }^{71}$ Acórdãos Danner e Skandia e, muito desenvolvidamente quanto a este ponto à luz da redacção do TCE que valia antes do Tratado de Amesterdão, as Conclusões apresentadas pelo Advogado-Geral TeSAURo no caso Safir.

72 Essa conformação com a jurisprudência assente é patente nas Conclusões da Advogada-Geral, apresentadas a 3 de Outubro de 2006 no âmbito do recente processo Comissão c. Bélgica.

${ }^{73}$ Directiva do Conselho, de 24 de Junho de 1988, para a execução do artigo $67 .^{\circ}$ do Tratado (JO L 178, p. 5) - ver anexo I, capítulo X, A. É certo que esta directiva não é aqui directamente aplicável, mas o seu anexo é frequentemente referido na jurisprudência do Tribunal de Justiça para delimitar o âmbito de aplicação da livre circulação de capitais - inclusivamente segundo a nova redacção dos artigos $56 .^{\circ}$ e segs. CE. Veja-se o acórdão de 16 de Março de 1999, Trummer e Mayer (C-222/ 197, Colect., p. I-1661, n. ${ }^{\circ}$ 21). Quanto à questão, cfr. CArrero, José Manuel Calderón, e JimÉnEZ, Adolfo Martín, «La armonización jurisprudencial de la imposición directa: las implicaciones fiscales del principio comunitário de no discriminación relación con las libertates básicas comunitarias», Manual de Fiscalidad Internacional, Instituto de Estudios Fiscales, 2004, pp. 1287 e ss. 
conta, sobretudo, os regimes do terceiro pilar da Segurança Social, esta nota abona, em nosso entender, a favor da precisão técnico-jurídica. No entanto, e atento, desde logo, o art. 58. ${ }^{\circ}$ do TCE, sempre se dirá que esta qualificação da conduta não terá um verdadeiro alcance prático nos casos como aqueles que têm sido apreciados - em que a alegada violação da livre circulação de capitais se acumula com a violação de outra liberdade fundamental.

\subsection{Conclusão}

Convoca-se aqui a sistematização usada pelo Advogado-Geral Geelhoed ${ }^{74}$ para concluir que as liberdades fundamentais podem ser prejudicadas por (i) normas de um Estado-Membro, não relevando aqui as normas que visam delimitar a jurisdição fiscal do Estado; ou (ii) pelo facto de coexistirem vários tipos de sistemas tributários dentro da União Europeia.

No primeiro grupo, reentram tanto as limitações das liberdades fundamentais determinadas por normas restritivas de liberdades fundamentais, como as determinadas por normas verdadeiramente discriminatórias. As limitações das liberdades fundamentais compreendidas no segundo grupo poderão, diferentemente, resultar de normas que restrinjam o efectivo exercício de uma liberdade fundamental. É nosso entendimento que as normas fiscais meramente restritivas i.e., sem conteúdo discriminatório - são, no actual estádio de integração europeia, exclusivamente inerentes à soberania dos Estados em matéria tributária.

${ }^{74}$ Citado em Weber, Dennis, «In Search of a (New) Equilibrium Between tax sovereignity and the Freedom of Movement Within the EC», Intertax, 12, vol. 34, 2006, p. 586. 


\section{AS REACÇÕES}

\section{Os actos normativos da União Europeia}

\subsection{Actos normativos: constatação e enquadramento de uma lacuna}

Ao contrário do que acontece em relação aos impostos indirectos ${ }^{75}$, o TCE não dispõe de regras específicas em relação à tributação directa. $\mathrm{O}$ que se pode explica, segundo Casalta Nabais, por, mesmo em sede de tributação indirecta, "a harmonização fiscal não constituir um fim em si mesmo, mas um meio para eliminar os obstáculos à livre circulação de mercadorias, pessoas, serviços e capitais dentro da Comunidade, e por, numa certa perspectiva, só os impostos indirectos, porque componentes do preço dos bens e serviços, constituírem obstáculo à referida livre circulação." ${ }^{\prime 76}$.

Como tal, vale aqui a regra geral sobre a aproximação de legislações constante do art. $94 .^{\circ}$ do TCE, impondo que as medidas normativas adoptadas em matéria fiscal tenham que ter a forma de directiva, adoptada pelo Conselho, deliberando por unanimidade, sob proposta da Comissão, e

${ }^{75}$ Arts. $90 .^{\circ}$ a $93 .^{\circ}$ do TCE. É relativamente pacífico que a referência a impostos indirectos que consta destes artigos do Tratado tem por base o critério económico stricto sensu ou da contabilidade nacional, nos termos do qual "são impostos directos aqueles que não constituem custos de produção das empresas e impostos indirectos os que constituem custos de produção das empresas." - cfr. Nabais, José Casalta, Direito Fiscal, Coimbra, Almedina, 2005, p. 43; quanto aos critérios da distinção entre impostos directos e indirectos, cfr. ainda pp. 42-50.

${ }^{76}$ Nabais, José Casalta, Por um Estado Fiscal Suportável - Estudos de Direito Fiscal, Coimbra, 2005, p. 195. Cfr. ainda nota anterior. 
após consulta do Parlamento Europeu e do Comité Económico e Social. Trata-se de uma regra estrita, tratando-se de uma das matérias que o art. $95^{\circ}$, n. $^{\circ} 2$, excepciona da harmonização através do procedimento de co-decisão (arts. $95 .^{\circ}$ e $21 .^{\circ}$ do TCE).

Esta regra tem desincentivado e mesmo frustrado a adopção de actos comunitários em matéria de fiscalidade directa $^{77}$. O sector em apreço não é excepção: já em 1992 a Comissão apresentou propostas de harmonização fiscal como parte de uma proposta de Directiva sobre investimento transfronteiriço e fundos de pensões; no entanto, dada a rejeição manifestada pelo Conselho em relação a esta matéria, as propostas acabaram por ser retiradas. Assim, a Comunidade tem-se manifestado, em matéria de tributação de regimes complementares de pensões, sobretudo através de actos não vinculativos, que procuram, sem que o consigam, lançar a ponte para uma harmonização normativa.

\subsection{A resposta possível: soft law emanada na matéria}

Embora outros actos comunitários houvessem já relevado o impacto da fiscalidade dos regimes complementares de reforma ${ }^{78}$, coube à Comissão Europeia, em 2001, através da sua Comunicação sobre a Eliminação dos obstáculos fiscais aos

77 Cfr., nesta matéria, o Parecer do Comité Económico e Social Europeu sobre A fiscalidade na UE: princípios comuns, convergência das normas fiscais e possibilidade de votação por maioria qualificada (JO C080 de 30.03 .2004 p. 0139 - 0147), pontos 9.1. e 9.1.1.

${ }^{78}$ Cfr. sobretudo o Livro Verde da Comissão Europeia Supplementary Pensions in the Single Market, de 1997, cit. supra, em nota, pp. 18 e 19. No âmbito em análise, este documento procede sobretudo à identificação de problemas, sugerindo uma abordagem com base no reconhecimento mútuo de legislações, mas sem que densifique vias de solução. 
regimes de pensões profissionais transfronteiras ${ }^{79}$, o mérito de analisar especificamente o estado da questão, propondo soluções para os problemas detectados ${ }^{80}$.

Sobre a Comunicação da Comissão, vieram pronunciar-se o Comité Económico e Social (CES), através de Parecer $^{81}$ e o Parlamento Europeu, através de Relatório ${ }^{82}$. Depois de uma recepção favorável do texto, o Conselho Europeu acabaria, durante o ano de 2002, por se mostrar incapaz de chegar a acordo quanto a medidas concretas de implementação da Comunicação ${ }^{83}$.

$\mathrm{Na}$ Comunicação, a Comissão analisa o contexto vigente, e constata que, da falta de coordenação entre os sistemas fiscais nacionais, resulta, desde logo, o prejuízo das liberdades comunitárias. A Moção integrante do Relatório apresentado pelo Parlamento Europeu salienta ainda que a coordenação fiscal, neste sector, está em linha com a abertura de mercado dos regimes de pensões de segundo pilar, permitindo

${ }^{79}$ Comunicação da Comissão ao Conselho, ao Parlamento Europeu e ao Comité Económico e Social - Eliminação dos obstáculos fiscais aos regimes de pensões profissionais transfronteiras, $\operatorname{COM(2001)~} 0214$ final.

${ }^{80}$ Relativamente às propostas constantes da Comunicação - e que se passará a descrever em texto -, cfr. Schoneville, Peter, "Safeguarding pension taxation rights in cross-border situations», in EC Tax Review, 2, 2005, pp. 78 e ss.

${ }^{81}$ Parecer do Comité Económico e Social sobre a Comunicação da Comissão ao Conselho, ao Parlamento Europeu e ao Comité Económico e Social: Eliminação dos obstáculos fiscais aos regimes de pensões profissionais transfronteiras, (JO C036, de 08.02.2002 p. 0053-0058).

${ }^{82}$ Report on the Commission communication on the elimination of tax obstacles to the cross-border provision of occupational pensions (A5-0388/2001 FINAL), composto por Moção para Resolução, pela qual foi responsável o Comité para Assuntos Económicos e Monetários, Parecer do Comité para o Emprego e Assuntos Sociais e Parecer do Comité para as Petições.

${ }^{83}$ Cfr. Relatório do Conselho Europeu n. ${ }^{\circ}$ 14508/02, de 19 de Novembro de 2002. 
comparar com mais acuidade os regimes e estimulando a mobilidade e o emprego. A Moção reconhece o crescente impacto orçamental das receitas fiscais associadas a estes regimes; no entanto, entendendo que a unanimidade exigida inviabilizará a adopção de acto normativo nesta sede, prescreve o recurso à coordenação.

Tal como os órgãos comunitários que se viriam a pronunciar na matéria, a Comissão sustenta, por outro lado, que as quatro liberdades fundamentais se opõem às disposições nacionais que condicionam a dedutibilidade de contribuições para regimes de reforma ao pagamento daquelas a uma instituição de pensão estabelecida no território nacional. A Comissão admite a hipótese de essa recusa se fundar em "justificação objectiva"; mas faz notar que todas as justificações apresentadas pelos Estados até à data se revelam imprestáveis ${ }^{84}$. Conclui, pois, que a dedução destas contribuições deverá valer nos mesmos termos em que vale face a instituições estabelecidas, apenas se admitindo o seu condicionamento ao cumprimento, pelo regime estrangeiro em causa, dos requisitos impostos para o efeito às instituições estabelecidas no país. Os mesmos princípios devem reger os casos de transferência de montantes a partir de instituições não estabelecidas no território: o Estado em causa apenas poderá tributar os montantes transferidos quando sujeitar a tributação uma transferência similar realizada entre duas estruturas situadas no seu território.

${ }^{84} \mathrm{Vd}$. quanto se dirá em II. 2.2. Diga-se, porém, que, em matéria de justificações invocadas ante o Tribunal de Justiça, a Comissão entende que a justificação relativa à coerência fiscal não se sustém quando consideradas as Convenções de Dupla Tributação celebradas pelo Estado em sede internacional; e que a recusa da dedução para garantir a cobrança de impostos pelo Estado-Membro em causa se revela desproporcionada face às possibilidades de obtenção de informação em relação aos pagamentos feitos por instituições estrangeiras. 
Em toda esta matéria, deverá, porém, segundo a Comissão, ser feita uma distinção de base, colocando de um lado os trabalhadores que, sendo residentes num Estado, optam por subscrever um contrato com uma instituição não estabelecida nesse território; e de outro lado os subscritores que, sendo trabalhadores migrantes, se tenham vinculado já no respectivo Estado de origem à instituição não estabelecida. Apenas no primeiro caso poderá haver o condicionamento da dedução ao cumprimento dos requisitos (ligados à política social do Estado) estabelecidos para a dedutibilidade das contribuições a favor de instituições estabelecidas. No segundo caso, deverá valer irrestritamente um princípio de reconhecimento mútuo das legislações: o Estado de acolhimento, quando preveja um regime de diferimento da tributação, deverá autorizar a correspondente dedução independentemente do cumprimento daqueles requisitos.

Na Moção apresentada, o Parlamento Europeu mostra o seu apoio genérico a estes entendimentos. Porém, mais comedidamente, impõe alguma prudência na matéria, admitindo que o reconhecimento mútuo de legislações seja limitado por duas ordens de razões: a necessidade de evitar abusos de dedução, e a evasão fiscal.

Por outro lado, tanto a Comissão, como os órgãos comunitários chamados a pronunciar-se, reconhecem o carácter decisivo da intervenção do Tribunal de Justiça na repressão das medidas estatais ilegítimas. A Comissão junta, inclusivamente, ao seu louvor o compromisso de cumprir, juntamente com este órgão, o seu papel de guardiã dos Tratados. Apenas a Moção do Parlamento Europeu, sem deixar de concordar no carácter desproporcionado e, como tal, ilegítimo, das disposições internas que recusam a dedutibilidade às contribuições feitas em beneficio de instituições não estabelecidas, faz notar o carácter puramente negativo da intervenção do Tribunal, parecendo esperar que esta mesma limitação force os Estados a uma acção construtiva. 
Procurando, seguidamente, apresentar vias para que os Estados logrem, com respeito dos Tratados, cobrar as respectivas receitas fiscais, a Comissão prescreve, fundamentalmente, quatro meios de acção.

Em primeiro lugar, a Comissão assinala a faculdade dos Estados-Membros de proceder à troca automática de informações, ao abrigo da Directiva "Assistência Mútua" ${ }^{85}$, devendo esta troca automática abranger informações relativas ao pagamento de pensões de reforma a residentes de outro Estado-Membro. Toda a exposição da Comissão é, nesta sede, dirigida a defender a eficácia da Directiva, contra a inoperância que lhe é apontada ${ }^{86}$. Assim, a Comissão procede à interpretação do art. $8 .^{\circ}$ do acto $^{87}$, defendendo que

${ }^{85}$ Directiva 77/799/CEE do Conselho, de 19 de Dezembro de 1977, relativa à assistência mútua das autoridades competentes dos Estados-Membros no domínio dos impostos directos, JO L336 de 27.12.1977, várias vezes alterada.

86 É bastante notória a descrença relativa ao funcionamento da Directiva na ironia de BARTho Pronk, nomeado relator pelo Comité para o Emprego e Assuntos Sociais para elaboração do respectivo Parecer: "The Commission proposes that the Mutual Assistance Directive of 1977 which already provides for the automatic exchange of information (!) should be effectively implemented.”. E, mais abaixo, em conclusão "The draftsman in principle welcomes the Commission's proposals. He would, however, like to point out that the ideas it contains are not new and that the Commission will therefore need to make special efforts to inject new life into its proposals. He therefore calls on the Commission to submit plans to transpose as soon as possible the measures that have been announced.".

${ }^{87}$ Do art. $8 .^{\circ}$ consta o seguinte: "Limites da troca de informações

1. A presente directiva não impõe a obrigação de promover investigações ou de transmitir informações, quando a legislação ou a prática administrativa do Estado-membro que deve fornecer as informações não autorizem a autoridade competente a efectuar essas investigações, nem a obter ou utilizar tais informações no próprio interesse desse Estado.

2. A transmissão de informações pode ser recusada quando conduza à 
este não permite a recusa do fornecimento de informações ante a mera invocação de que as informações não seriam necessárias para fins de tributação interna, mas que é invocável apenas quando o próprio Estado requerido as não possa recolher ou usar para os seus próprios fins ${ }^{88}$.

Tanto o CES, como o Parlamento Europeu, se vieram mostrar favoráveis à adopção deste acto como base para a troca de informações neste âmbito. Embora por princípio o desaconselhe, o CES admite ainda, como factor de tranquilização das autoridades fiscais dos Estados-Membros, o recurso a representantes fiscais, residentes nos Estados-Membros onde se realize a prestação de trabalho, nomeados pela empresa participante do esquema de pensões. Estes representantes ficariam responsáveis, perante as autoridades fiscais locais, pela cobrança do imposto devido pelos residentes vinculados ao regime de outro país.

Naquilo que o relator BARTHO PRONK considerou a parte verdadeiramente inovadora da Comunicação, propôs-se ainda a criação de uma instituição de pensão pan-euro-peia.

"Em termos práticos, a instituição de pensão pan-europeia estabelecida num Estado-Membro teria várias secções, funcionando cada uma de acordo com os requisitos para aprovação fiscal e respeitando a regulamentação fiscal e a legislação social do Estado em que o trabalhador desempenha

divulgação de um segredo comercial, industrial ou profissional ou de um processo comercial, ou de uma informação cuja divulgação seja contrária à ordem pública.

3. A autoridade competente de um Estado-membro pode recusar a transmissão de informações quando o Estado interessado não se encontre em situação de fornecer informações correspondentes, por razões de facto ou de direito.".

88 A Comissão propõe ainda que esta troca ocorra através do comité previsto no art. $9 .^{\circ}$ da Directiva, sugerindo que no seio deste se analise a hipótese, menos onerosa, de a troca ocorrer directamente entre as instituições de pensão e os Estados-Membros em causa. Fornece, por último, com todo o detalhe, um limiar mínimo de informação a prestar. 
a sua actividade." Ou seja, embora a instituição pan-europeia fosse uma única entidade, estabelecida num Estado-Membro e sujeita apenas à fiscalização correspondente, cada uma das diferentes secções seria de facto tratada para efeitos fiscais como estando estabelecida no território do Estado-Membro correspondente e aplicar-se-lhe-iam as mesmas regras e procedimentos que a uma instituição de pensão nacional, nomeadamente as regras respeitantes à aplicação do imposto sobre o rendimento ou à retenção do imposto na fonte. Assim, caso o trabalhador se transferisse para outro Estado-Membro no decurso da respectiva carreira, continuaria a pagar cotizações à mesma instituição de pensão pan-europeia, embora numa secção diferente, não havendo lugar à transferência de direitos acumulados entre as diferentes secções. Após a reforma, o trabalhador receberia pensões de reforma de cada secção nacional de acordo com os direitos adquiridos nos termos da regulamentação nacional aplicável a essas secções. Caso o trabalhador se estabelecesse, na altura da reforma ou posteriormente, num Estado-Membro diferente daquele em que tivesse estado empregado, seria transferido para a secção desse Estado-Membro (caso existisse).

Esta estrutura certamente seria apta a alargar, de modo espontâneo, as deduções previstas para as contribuições efectuadas junto de regimes locais. Deve, no entanto, dizer-se que a mesma não substitui nem prescinde da harmonização de legislações fiscais para que possa evitar a dupla tributação. Desde logo, porque, como a própria Comissão o admite, impõe aos Estados-Membros das secções pertinentes da instituição de pensão pan-Europeia a garantia da isenção face a eventuais impostos cobrados pelo Estado-Membro onde estejam estabelecidas. E, por outro lado, não exime um subscritor que não tenha beneficiado de deduções à dupla tributação dos montantes em causa, quando o Estado da residência ao tempo da reforma os tribute. 
Isto mesmo parece ser reconhecido pela Moção do Parlamento Europeu. Note-se ainda que nem todas as instituições terão escala para instalar secções nos 27 Estados-Membros actuais - pelo que o benefício das vantagens ligadas a esta instituição pan-europeia pode estar condicionado à - e ser desincentivado pela - transferência dos contratos de seguro ou planos de pensões para outra instituição.

Em terceiro lugar, a Comissão recomenda a adopção generalizada do princípio EET na União Europeia. Para além de reconhecer as vantagens aliadas a este sistema, a Comissão salienta, de um ponto de vista prático, a aplicação deste sistema por doze ${ }^{89}$ dos (então) quinze Estados-Membros. Reconhece, no entanto, que esta adopção não resolveria os problemas derivados das diferenças entre os sistemas de tributação dos Estados-Membros. Como acima se referiu, a resolução destes problemas imporia que valesse um princípio do reconhecimento mútuo das legislações, antes de mais, no tocante às condições estabelecidas para o reconhecimento dos esquemas como correspondentes a um direito à dedução, e no montante das deduções permitidas. Assim entendeu, aliás, o Comité para o Emprego e os Assuntos Sociais, através do Parecer emitido.

Por último, a Comissão oferece o seu apoio técnico aos Estados na adopção das medidas necessárias para a eliminação dos obstáculos injustificados à liberdade de circulação de trabalhadores, resultantes da diversidade dos regimes fiscais dos Estados-Membros em matéria de pensões de reforma, particularmente em matéria de dupla tributação. Este objectivo poderia ser conseguido, quando não tivesse sido possível a dedução das quotizações, mediante a previsão de isenções pelo Estado-Membro a que cumpra a tributação

${ }^{89} \mathrm{Ou}$ seja, por onze Estados e pela Alemanha, que aplicava o modelo EET ou TTE em função do tipo de esquema em causa. 
dos montantes pagos a final. Ou, quando o Estado da fonte permitisse a dedução das contribuições ao rendimento auferido na fonte, mediante limitação dos poderes tributários do Estado da residência através da previsão de cláusulas de matching credit ${ }^{90}$. Essas medidas para eliminação da dupla tributação tanto poderiam ter carácter unilateral, como constar de Convenções para Evitar a Dupla Tributação celebradas pelos Estados.

Neste ponto, o CES acusa Comissão de não ter aprofundado o bastante os problemas levantados pela sobreposição de ordenamentos fiscais. Assim, por exemplo, fica por esclarecer como pode um Estado ETT aplicar as suas disposições fiscais a um esquema não estabelecido no território - ou seja, como pode, no fundo, este Estado tributar o rendimento gerado numa estrutura situada noutro Estado-Membro.

Recomenda-se ainda a coordenação de sistemas - desde logo, mediante a adopção de uma convenção multilateral, ao abrigo do art. 293. ${ }^{\circ}$ do Tratado. Por sua vez, o CES considera preferível o mecanismo da Directiva, entendendo, sem as reservas que na matéria coloca o Parlamento Europeu, que esta deve ter por objecto tanto o $2 .^{\circ}$, como o $3 .^{\circ}$ pilares da Segurança Social. Já o Parlamento Europeu propõe, na Moção apresentada, a coordenação pelo recurso ao mecanismo da cooperação reforçada introduzido pelo Tratado de Nice.

${ }^{90}$ Ou seja, através de cláusulas de crédito presumido, o qual "consiste na atribuição [pelo Estado da residência] de um crédito mais elevado do que o que resultaria da aplicação da taxa convencional ou de direito comum no Estado da fonte", sendo, assim, o crédito de imposto fixado a forfait (cfr. XAvier, Alberto, Direito Tributário Internacional, 2a Edição, Almedina, 2007, p. 752). 
Estas propostas chegaram a ser debatidas no seio do Conselho. No entanto, embora os Estados-Membros aí reconhecessem a ocorrência e complexidade dos problemas identificados, não lograram obter consenso quanto aos modos para lhes dar solução.

\section{A intervenção do TJCE}

Da leitura do que até agora se expôs, bem se pode antecipar que o papel preponderante em matéria de coordenação das legislações dos Estados-Membros tem sido desempenhado pelo Tribunal de Justiça ${ }^{91}$. Conforme se disse, a sua intervenção tem sido suscitada para a apreciação de disposições fiscais de Estados-Membros, que, prevendo regimes EET ou ETT, negam a vantagem da dedução das contribuições quando estas contribuições sejam pagas a instituições não residentes.

A abordagem da jurisprudência pode, para o que aqui releva, ser dividida em dois momentos: o momento de qualificação da colisão entre as disposições nacionais e as liberdades fundamentais (2.1.); e o momento da consideração dos fundamentos que, na óptica dos Estados-Membros, poderiam justificar a subsistência dessa incompatibilidade (2.2.).

${ }^{91}$ Para uma exposição de parte do rol dos acórdãos que consubstanciam o contributo do Tribunal de Justiça em matéria de tributação directa, cfr. Marchessou, Philippe, e Pérez, Susana Aníbarro, «Direct taxation and fundamental freedoms of the Community: an approach to the contribution of the European Court of Justice», Diritto e Pratica Tributaria Internazionale, 4, 2004, pp. 425 e ss. 


\subsection{A qualificação da colisão entre as disposições naci- onais $e$ as liberdades fundamentais}

A jurisprudência do Tribunal de Justiça tem sido errática em matéria de qualificação das incompatibilidades detectadas entre medidas nacionais e liberdades fundamentais. Ora, de acordo com a jurisprudência do Tribunal, a questão da qualificação das incompatibilidades não é meramente terminológica, mas de apreciável relevo prático.

Tal como acima se deixou aflorado, o Tratado tem por pedra-de-toque a proibição da discriminação em razão da nacionalidade (art. $12^{\circ}$ ). Coube à jurisprudência do Tribunal de Justiça desenvolver este conceito, entendendo-se, desde o processo Itália c. Comissãa ${ }^{92}$, que existe discriminação quando situações similares são tratadas de forma distinta, ou quando situações distintas são tratadas de forma idêntica. Não se proíbem unicamente as discriminações directas - hoc sensu, em razão da nacionalidade -, mas também aquelas que, empregando critérios diversos do da nacionalidade ${ }^{93}$ (maxime, o da residência ${ }^{94}$ ), produzam o mesmo efeito - as discriminações indirectas ou encobertas ${ }^{95}$.

92 Processo 13/63, Itália c. Comissão, Colect. 1963, p. 360.

93 O que acontece, desde logo, nos casos de discriminação do investimento estrangeiro feito por sujeitos nacionais, e que configuram uma 'discriminação às avessas' (reverse discrimination) - cfr., paradigmaticamente, o caso Asscher (C-107/94).

${ }^{94}$ Assim, o Advogado-Geral Mischo, em Conclusões apresentadas em 17 de Setembro de 1991, relativamente aos casos Comissão c. Bélgica e Bachmann (Colect. 1992, p. I-0249), que sustentou que a norma que negava a dedução de contribuições entregues a seguradoras não estabelecidas afectaria, em termos proporcionais, sobretudo trabalhadores estrangeiros.

${ }^{55}$ Quanto a este ponto, cfr. Carrero, José Manuel Calderón, e JimÉNEZ, Adolfo Martín, «La armonización jurisprudencial de la impo- 
Em alternativa, o Tribunal ${ }^{96}$ usa ainda o par conceptual que contrapõe medidas formalmente discriminatórias, enquanto medidas que estabelecem um regime distinto para nacionais de outros Estados-membros, a medidas formalmente não discriminatórias. As últimas são, nesta sede ${ }^{97}$, entendidas enquanto medidas que, embora indistintamente aplicáveis a nacionais de outros Estados-membros, podem ter um efeito discriminatório, quanto determinem a aplicação de regras iguais a situações que não sejam comparáveis.

Tradicionalmente, nos casos em que se pronuncia pela existência de uma verdadeira discriminação, o Tribunal rejeita a invocação, para a respectiva justificação, de qualquer fundamento não expressamente previsto no Tratado ${ }^{98}$ (processos Royal Bank of Scotland e Bond van Adverteerders ${ }^{99}$, por exemplo). Diferentemente, nos casos em que entende que se está face a uma discriminação meramente indirecta, ou face a uma medida formalmente não discriminatória, o

sición directa: las implicaciones fiscales del principio comunitário de no discriminación relación con las libertates básicas comunitarias», Manual de Fiscalidad Internacional, Instituto de Estudios Fiscales, 2004, pp. 1187 e ss., e jurisprudência aí citada.

96 Acórdão de 4 de Dezembro de 1986, Comissão/Alemanha (205/84, Colect., p. 3755, n. 25) e acórdão de 9 de Julho de 1997, Parodi (C-222/95, Colect., p. I-3899, n._ 21.

97 Trata-se de uma importação de definições desenvolvidas no âmbito da livre circulação de mercadorias, em que medidas formalmente discriminatórias são aquelas distintamente aplicáveis a produtos importados ou exportados. Cfr., quanto a estas categorias, Cunha, Patrícia Noiret da, A tributação directa na jurisprudência do Tribunal de Justiça, Coimbra Editora, 2006, pp. 180-181.

${ }^{98} \mathrm{Ou}$ seja, de qualquer fundamento não compreendido nos artigos 39. ${ }^{\circ}$, n. $^{\circ} 3,45^{\circ}, 46 .^{\circ}$ (cfr. também art. $55^{\circ}$ ) e $58 .^{\circ}$ do TCE.

99 Acórdão de 26 de Abril de 1988 (352/85, Colect., p. 2085, n. 32); cfr. também a restante jurisprudência citada nas Conclusões do Advogado-Geral. 
Tribunal admite a justificação da medida, desde que proporcionada, à luz de não taxativas razões imperiosas de interesse geral $^{100}$.

Por outro lado, a situação de incompatibilidade face ao Tratado pode manifestar-se através de uma restrição, directa ou indirecta, ao exercício efectivo das liberdades comunitárias. Criam uma restrição todas as normas que obstaculizem a plena realização das liberdades fundamentais, mesmo que se apliquem indistintamente nacionais e a não nacionais. Assim, o âmbito da restrição mostra-se mais lato do que o campo estrito da discriminação, englobando obstáculos fundados não na natureza das normas nacionais, mas na existência de disparidades entre os ordenamentos nacionais.

Trata-se de uma noção consentânea com a ideia de construção de um mercado interno, que adveio ao âmbito da fiscalidade directa por importação da jurisprudência desenvolvida em matéria de livre circulação de mercadorias (acórdão Cassis de Dijon ${ }^{101}$ ), na qual, contrabalançando a latitude do vector da integração comunitária, o Tribunal permite a justificação das medidas restritivas com fundamento em razões de interesse geral não constantes do Tratado (rule of reason).

Ora, na casuística do Tribunal, este tanto recusa a análise de justificações fundadas no interesse geral, dado o carácter discriminatório da norma interna em causa (processos Royal Bank of Scotland e Ciola, por exemplo), como qualifica as normas em causa como medidas restritivas, ou mesmo se furta à respectiva qualificação expressa como discriminatórias (qualificando-as como um 'obstáculo' ou

100 Assim, no processo O'Flynn c. Adjudication Officer (C-237/94, Colect., p. I-2617), cit. ap. FArmer, Paul, «The Court's case law on taxation: a castle built on shifting sands?», EC Tax Review, 2, 2003, pp. 75 e ss.

101 Acórdão de 20 de Fevereiro de 1979 (120/78). 
como geradoras de "diferenças de tratamento" - Comissão c. Bélgica, Bachmann, Danner, Skandia, Comissão c. Dinamarca) apesar de, face a estas, procederem aparentemente razões similares às sufragadas nos casos de discriminação, e avalia as excepções de interesse geral invocadas.

$\mathrm{Na}$ matéria que especificamente analisamos, em que está, em quase todos os casos apreciados, em causa o condicionamento da concessão de uma vantagem fiscal (dedução fiscal do montante das contribuições efectuadas) ao estabelecimento do prestador de serviços no território, verificase uma nota especial de entropia. Na verdade, o Tribunal ${ }^{102}$ já entendeu que uma medida seria formalmente discriminatória quando previsse um regime diferente para sujeitos não nacionais, ou para prestações de serviços não originárias do Estado-Membro em causa; e que a medida seria já considerada indistintamente aplicável quando estabelecesse, como critério para aceder a determinado regime, a residência o estabelecimento no território. Já segundo a jurisprudência Svensson e Gustavsonn ${ }^{103}$, a exigência de estabelecimento no território para a aplicação de certo regime constituiria uma discriminação em razão do estabelecimento, devendo ser fundada numa das razões previstas no art. 56..$^{\circ}$ (hoje, art. 46. ${ }^{\circ}$ ) do TCE, para que o art. $66^{\circ}{ }^{(h o j e,}$ art. $55 .^{\circ}$, remete) ${ }^{104}$. Mesmo em relação ao critério "residência", em causa no caso Wielockx, a oscilação é idêntica. Assim, ao invés do

102 Acórdão de 4 de Dezembro de 1986, dito «seguros», Comissão/ /Alemanha (205/84, Colect., p. 3755, n. 25) e acórdão de 9 de Julho de 1997, Parodi (C-222/95, Colect., p. I-3899, n. 21.

103 Acórdão de 14 de Novembro de 1995, Svensson e Gustavsonn (C-484/93, Colect., p. I-3955).

${ }^{104}$ O próprio Ac. Svensson e Gustavsonn não logra, porém, estabelecer jurisprudência inequívoca, entrando, depois da referida afirmação, contraditoriamente na discussão da excepção da coerência fiscal, invocada no caso. 
que entendeu nos primeiros dois acórdãos referidos, o Tribunal veio defender que uma distinção fundada exclusivamente no critério da residência pode encobrir uma distinção fundada na nacionalidade ${ }^{105}$

A insegurança jurídica, bem como as incongruências derivadas desta variedade de abordagens, foram por várias vezes denunciadas, pela doutrina (FARMER), bem como pelos Advogados-Gerais, em Conclusões apresentadas nesta sede. Em todas essas ocasiões o Tribunal foi - infrutiferamente instado a pronunciar-se de modo claro sobre as questões.

Desde logo, o Advogado TesAuro apontou a incoerência do juízo do Tribunal aplicado em matéria de livre prestação de serviços, na parte em que considera discriminatória a diferenciação segundo a fonte da prestação de serviços, e não discriminatória a diferenciação segundo o estabelecimento ou não no território. Com efeito, exigir que o prestador se estabeleça no território para que efectue a prestação equivale a exigir que a prestação tenha, afinal, por fonte o território nacional. Assim, o Advogado-Geral considera que também as medidas que discriminem em razão do estabelecimento devem ser consideradas discriminatórias, embora apenas o sejam indirectamente, uma vez que não se fundam especificamente no critério da nacionalidade. Estas discriminações indirectas deverão ser analisadas pelo Tribunal, devendo este enquadrá-las entre as medidas indistintamente aplicáveis, ou entre as formalmente discriminatórias, apenas no primeiro caso sendo possível a análise de justificações apresentadas que não estejam previstas nos Tratados.

Também o Advogado-Geral JaCoBs tocou em particular este ponto, nas Conclusões apresentadas no caso Danner.

105 Cfr. a jurisprudência citada pelo Advogado-Geral LÉGER, nas Conclusões apresentadas no processo Wielockx: Acórdão de 8 de Maio de 1990, Biehl (C-175/88, Colect. p. I-1779); Acórdão Bachmann e Acórdão Schumacker, citados acima. 
Neste caso, a norma interna que permitia a dedução aplicava-se não apenas a instituições estabelecidas no território, como também a instituições nacionais, mesmo que não estivessem estabelecidas $^{106}$. O Advogado-Geral considerou que aqui se estaria sempre ante uma verdadeira norma discriminatória. Não deixou, no entanto, o debate cessar nesse ponto, porque considerou, desde logo contra o entendimento manifestado por Tesauro, que, a admitir a invocação de excepções não previstas no Tratado, esta hipótese deve valer quer face a normas verdadeiramente discriminatórias (em apreço), quer face a normas que se considerassem meras restrições às liberdades. Antes de mais, porque o próprio TCE não faz uma partição estanque entre um e outro dos casos. Por outro lado, o Advogado relembra que as situações são, muitas das vezes, de qualificação dúbia. Além disso, existiriam vários objectivos de interesse geral e legítimo não expressamente referidos no Tratado (protecção ambiental, vg.), a que deveria ser dada guarida. Como tal, entende o Advogado que, se a excepção constituir um objectivo legítimo de interesse geral, deverá ser invocável para justificar a disposição interna, desde que esta respeite o princípio da proporcionalidade. Por outro lado, o critério da proporcionalidade deve ser tanto mais exigente quanto mais discriminatória for a medida.

Mais recentemente, a Advogada-Geral STIX-HAcKL, em Conclusões apresentadas no caso Comissão c. Dinamarca, veio considerar (contra JACOBS, com LÉGER) que uma situação como as apreciadas na jurisprudência em causa se trata de

${ }^{106}$ Embora, literalmente, o mesmo parecesse resultar da fattispecie sueca, em causa no caso Safir, o Advogado-Geral entendeu, com base em todos os elementos disponibilizados no processo, que, relevante para a aplicação da norma de dedução era o estabelecimento em território sueco, e não a nacionalidade sueca. 
discriminação indirecta, e não directa. Segundo a Advogada, uma vez que o benefício apenas é negado às seguradoras estrangeiras quando estas não estejam estabelecidas, deve entender-se que a regulamentação nacional não distingue em função da sede ou nacionalidade da prestadora, mas sim em função da origem da prestação. Assim, poderá ser justificada com base em razões imperativas de interesse geral não previstas no Tratado (Bachmann, Comissão/Bélgica, Asscher, Danner). Por outro lado, entende que não se trata de uma mera restrição.

Quanto a toda esta questão, não se pode deixar de sufragar a preocupação manifestada pelos Advogados-Gerais: uma vez que o Tribunal de Justiça insiste em retirar consequências da distinção entre medidas formalmente discriminatórias e medidas indistintamente aplicáveis, deveria, pelo menos, precisar os termos da distinção.

Não nos parece, porém, que seja essa a hipótese mais correcta. No actual estádio da integração europeia, não se vislumbra espaço para o acolhimento, sem mais, do princípio do reconhecimento mútuo das legislações em matéria fiscal ${ }^{107}$. Desde logo, porque não há, no espaço comunitário,

107 Contra, Frans VAnistendael, que entende que o objectivo da total integração do mercado comunitário impõe um critério mais abrangente que o da não discriminação - o critério absoluto da ausência de restrição. VANISTENDAEL defende, em consequência, que a soberania fiscal dos Estados-Membros passa a residir no direito de determinar o volume geral da sua receita fiscal, mas não a forma exacta como a tributação atingirá os contribuintes (VANISTENDAEL, Frans, «Cohesion: the phoenix rises from his ashes», EC Tax Review, 4, 2005). Para além do que dizemos em texto, salientamos que uma concepção minimalista da soberania fiscal dos Estados-Membros poderá colocar entraves sérios aos mecanismos de que estes se possam servir para tornar efectivo o seu sistema fiscal, fazendo perigar a própria previsibilidade do "volume geral de receitas". No sentido do texto, Dennis Weber (Weber, Dennis, "In 
uma aproximação das bases de tributação, ou das normas de determinação de imposto, que sustente esse reconhecimento mútuo.

Nem parece correcto que este reconhecimento seja imposto à outrance, por um órgão jurisprudencial ${ }^{108}$, em moldes similares aos que presidiram à imposição do princípio em matéria de livre circulação de mercadorias. Trata-se aqui de matéria fiscal, que verdadeiramente estrutura o que remanesce da soberania dos Estados em matéria de receitas orçamentais. Pelo que não pode o Tribunal substituir-se ao consentimento dos Estados no abdicar de parcelas de soberania fiscal - sobretudo, quando este consentimento não foi manifestado pelos Estados em sede de Direito Comunitário originário ou derivado. E mais ainda quando a perda de receita fiscal do Estado não é por qualquer modo compensada ou tida em conta através de um orçamento comunitário ${ }^{109}$.

Pelo que se entende que a intervenção do Tribunal de Justiça está reservada aos casos em que as normas internas

Search of a (New) Equilibrium Between tax sovereignity and the Freedom of Movement Within the EC", Intertax, 12, vol. 34, 2006, pp. 591 e ss); o A. baseia, porém, a sua argumentação na referida per-country approach, que, como referido acima, em nota, não se pode aceitar.

${ }^{108}$ Cuja actuação apenas pode ter um relevo negativo ou destrutivo dos sistemas fiscais, determinando o afastamento de determinadas normas que os integrem (cfr. Nabais, José Casalta, Por um Estado Fiscal Suportável - Estudos de Direito Fiscal, Coimbra, 2005).

${ }^{109}$ Sobre a exiguidade do Orçamento comunitário, cfr., por todos, Quelhas, José Manuel Santos, «A Agenda 2000 e o Sistema de Financiamento da União Europeia», Temas de Integração, n. ${ }^{\circ}$ 5, 3. ${ }^{\circ}$ Volume, 1998. Da exiguidade deste Orçamento comunitário, distante de qualquer pretensão federalizante, não podem deixar de ser retiradas consequências quanto a pretensões federalizantes que se queira impor aos Estados em matéria de acesso a receitas próprias. Cfr. também Nunes, A.J. Avelãs, Economia -II - O Crédito, Serviços de Acção Social da U.C., 2004, maxime pp. 310 e ss. 
tenham um conteúdo discriminatório ${ }^{110}$. O que, na jurisprudência relativa à tributação directa dos esquemas de pensões complementares, nunca deixou de acontecer. Como, aliás, o salienta PAUL FARMER em relação à tendencial totalidade da jurisprudência comunitária sobre tributação directa: apesar das flutuações de qualificação, "all the obstacles which the Court has had to consider in tax cases could be said to be discriminatory." "111.

Por outro lado - no que se acompanha o Advogado JACOBs - não parece que se deva reservar aos casos de discriminação indirecta a possibilidade de justificação com base em razões de interesse geral não expressas no Tratado. A divergência entre a Advogada STIX-Hackl e o Advogado JACOBS parece bastante ilustrativa a este respeito. A propósito de disposições idênticas, o Advogado entende que há lugar a uma discriminação directa, e a Advogada entende que há lugar a uma discriminação indirecta, retirando daí as consequências. E, com efeito, para que se discrimine directamente com base no critério da nacionalidade, terá que se estabelecer a nacionalidade como requisito exclusivo para aceder a determinado benefício (STIX-HACKL)? Ou também existe

110 Admitindo embora a apreciação de normas restritivas pelo Tribunal nesta sede, RicAHRD Lyal defende que esta possibilidade deve ser contrabalançada pela admissibilidade da invocação de um espectro lato de excepções de interesse público (Lyal, Richard, «Non-discrimination and direct tax in Community Law», Ec Tax Review, 2, 2003). Assumidamente na mesma linha, HinnEKEns chama a atenção para o desejável equilíbrio entre as liberdades que fundam o mercado interno e a soberania fiscal dos Estados-Membros, que se opõe a uma europeização da ordem fiscal interna (HinNeKENS, Luc, «European court goes for robust tax principles for treaty freedoms. What about reasonable exceptions and balances?», in EC Tax Review, 2, 2004, pp. 65 e ss.)

$111 \mathrm{O}$ A. excepciona da afirmação em texto apenas o caso Futura (FArmer, Paul , "The Court's case law on taxation: a castle built on shifting sands?», EC Tax Review, 2, 2003, p. 81). 
essa discriminação quando, mesmo que os não nacionais também possam aceder ao benefício, tenham que cumprir requisitos adicionais não exigidos aos nacionais (JACOBS)?

Parece-nos que a segunda posição é a mais acertada sendo mais ou menos ilegítimos os requisitos adicionais impostos aos não nacionais, o critério que os impõe é o da nacionalidade. A posição da Advogada não é, contudo, indefensável; nem se pode dizer que a diferença entre um e outro dos entendimentos assente em importantes razões de fundo. Não nos parece, pois, legítimo, fazer corresponder regimes diferenciados aos dois tipos de discriminações.

Por outro lado, e com o Advogado JACOBS, não parece que o Tratado tenha acolhido uma terminologia rígida (inclusivamente, tanto falando em obstáculos, como em discriminações, como em restrições). Nem que a prática actual consinta uma leitura rígida das disposições do Tratado - assim, embora o conceito de discriminação apareça no Tratado exclusivamente associado ao critério da nacionalidade (art. $\left.12 .^{\circ}\right)$, não parece que se possa transpor com pertinência este juízo para o campo da discriminação entre pessoas colectivas, no qual o relevo material da nacionalidade pode ser muito ténue.

Parece, pois, que se deve considerar que uma discriminação existe quando se estabeleça uma diferenciação de tratamento que desfavoreça um nacional comunitário no acesso à fruição de determinada liberdade fundamental, mesmo que o critério de diferenciação não seja o da nacionalidade. E que esta discriminação, quando materializada numa medida estadual, poderá ser justificada pela prossecução de objectivos de interesse geral, desde que com cumprimento do critério da proporcionalidade. 


\subsection{Razões invocadas para justificar a discriminação}

Com as sobreditas imprecisões e oscilações terminológicas, o Tribunal tem, porém, sempre convergido num ponto: o da tomada em consideração das razões de interesse geral invocadas pelos Estados para sustentar a previsão de diferenciações de regime. Passaremos, de seguida, à consideração das mais relevantes das excepções invocadas perante o Tribunal: a excepção da coerência fiscal (a), e a relativa à eficácia dos controlos fiscais $\mathbf{( b ) ^ { 1 1 2 }}$.

\section{(a) Coerência fiscal}

A excepção da coerência fiscal foi expressamente aceite nos casos Comissão c. Bélgica e Bachmann. Num e noutro caso, entendeu-se que havia uma coerência própria do sistema fiscal belga, relativamente à fiscalidade das pensões e dos seguros de vida. Nos termos das normas fiscais aplicadas a

${ }^{112}$ Assim, não analisaremos a excepção da falta de harmonização fiscal entre Estados-Membros (Comissão c. Bélgica e Bachmann), nem o argumento de maioria de razão, segundo o qual da liberdade dos Estados para condicionar a conclusão de contratos de seguros com instituições estrangeiras a uma autorização estadual por motivos de proteção do consumidor, decorreria a liberdade para negar uma vantagem fiscal àquelas (Bachmann), nem as justificações da garantia da concorrência e da necessidade de preencher o vazio fiscal que resultaria da não tributação da poupança sob a forma de seguros de vida em capital (Safir), ou a relativa à preservação da integridade da matéria colectável/ preservação a montante das receitas fiscais (Danner). À patente improcedência das duas primeiras, junta-se a menor densidade (por comparação com as excepções tratadas em texto) das restantes, quer no que toca aos moldes da respectiva invocação, quer no que toca aos moldes da resposta merecida por parte do Tribunal e Advogados-Gerais. Assim, com o assumido propósito concorrente de não alongar demasiado a exposição, opta-se por desenvolver apenas as que, pelo seu desenvolvimento e invocação reiterada, se mostram as mais relevantes das excepções invocadas. 
estas figuras, haveria uma conexão entre a dedutibilidade das contribuições e a sujeição a imposto das somas pagas pelos seguradores ao abrigo de contratos de seguro, gerando-se uma compensação entre a perda de receita fiscal correspondente às deduções permitidas, e a arrecadação de receita no momento do pagamento, pela seguradora, dos montantes devidos ao abrigo do contrato. Em termos tais que, quando não tivesse havido dedução do valor das contribuições efectuadas, os montantes pagos pela seguradora estariam isentos de imposto. A mesma coesão imporia que, caso o Estado fosse obrigado a estender a dedução às importâncias pagas noutro Estado, deveria poder tributar os correspondentes montantes pagos pela seguradora.

Face ao teste da proporcionalidade ${ }^{113}$, o Tribunal concluiu que, no estado da lei comunitária então vigente, não haveria meio menos restritivo de assegurar a coerência do sistema fiscal. Um compromisso assumido pela seguradora não seria bastante, pois, caso o compromisso não fosse honrado, teria que ser executado no Estado Membro em que estivesse estabelecida - o que poderia, desde logo, não ser permitido pelas normas desse Estado. Por outro lado, a prestação de garantia pela seguradora implicaria um aumento dos custos suportados por esta, certamente repercutido sobre os prémios - revelando-se mais restritivo que o expediente actualmente vigente.

O Tribunal reconheceu ainda que existiriam convenções bilaterais celebradas pelo Estado Membro - inclusivamente reconhecendo o direito à dedução das contribuições relativas a contrato de seguro, ainda que pagas em Estado

${ }^{113}$ Faz-se notar que foi neste ponto que o Advogado-Geral Mischo entendeu que a 'compensação' (o termo 'coerência' não surge ainda na Opinião do Advogado-Geral) invocada pelo Estado belga não deveria proceder. 
Membro diferente do Estado que concede o benefício - que atribuiriam exclusivamente a um dos Estados o poder de tributar os montantes pagos ao abrigo do contrato de seguro. Sustentou, porém, que este tipo de solução apenas é possível exactamente ao abrigo de convenções, ou através da adopção de medidas de harmonização pelo Conselho, não cabendo ao Tribunal extrair consequências da eventual celebração daquelas.

O Tribunal não mais viria a admitir, em matéria de tributação de regimes complementares da segurança social, a invocação desta excepção ${ }^{114}$. Assim, com parca casuística para verdadeiramente apreender o alcance da excepção permitida pelo Tribunal, os intervenientes nos ulteriores processos fizeram uma aplicação aparentemente acrítica e, muitas vezes, demasiado literal, desta jurisprudência.

Antes de passar à análise dessa casuística, convém que nos detenhamos num importante passo intermédio: o acórdão Wielockx.

Coube ao Advogado LÉGER, nas Conclusões apresentadas, lançar as bases da jurisprudência que se viria a firmar.

${ }^{114}$ Em parte, supõe-se, devido à severa crítica de que foi alvo a decisão final (tendo voz, nomeadamente, em Hinnekens e SCHelpe). Desde logo, porquanto a relação directa entre dedutibilidade e tributação não se verificava realmente, à face do sistema belga - no caso dos prémios de seguros de grupo, por exemplo, as pensões pagas seriam sempre tributáveis na esfera do beneficiário, quer tivessem ou não os prémios sido deduzidos. Por outro lado, criticou-se a noção vaga de coerência fiscal formulada no Acórdão, bem como o facto de este não ter em consideração a quebra daquela correlação por força de ADT's celebrados pelo Estado belga. Quanto a esta crítica, cfr. BRABANTER, Véronique De, «The Danner case: elimination o Finnish tax obstacles to the cross-border contributions to voluntary pension schemes», EC Tax Review, 3, 2003, pp. 167 e ss. e Vanistendael, Frans, "Cohesion: the phoenix rises from his ashes», EC Tax Review, 4, 2005. 
Assim, o Advogado começa por reconhecer que, desde o Ac. Bachmann, é permitido a um Estado, em nome do princípio da coerência fiscal, fundar o regime fiscal de um certo tipo de pensões na correlação entre a dedutibilidade das contribuições (por razões sociais ou de incentivo empresarial) e a imposição das pensões pagas (por razões orçamentais). Porém, no caso Wielockx, o sistema fiscal não fundaria a sua coerência nesta correlação.

O Advogado entende que todos os Estados (e, no universo da União Europeia, seriam quase todos) que celebram convenções de dupla tributação de acordo com o modelo proposto pela OCDE renunciam àquele princípio de correlação. Com efeito, de acordo com o texto da CMOCDE $\left(\right.$ art. $\left.18 .^{\circ}\right)$, as pensões e outras remunerações similares, pagas a um residente por força de um emprego anterior, apenas são tributáveis no Estado da residência. O Advogado considera, então, que, por força das convenções contra a dupla tributação que integram o direito fiscal nacional e se impõem às normas fiscais internas, a coerência passa a situar-se a outro nível - o Estado tributa todas as pensões percebidas por residentes do seu território, independentemente do território em que estas foram pagas. Em contrapartida, renuncia a receber imposto em relação a pensões pagas no estrangeiro, mesmo se estas tiverem por origem e por contrapartida contribuições pagas no seu território, e que tenha considerado dedutíveis (assim, doutrinalmente, Hinnekens e Schelpe).

Poder-se-ia considerar, como se fez no Acórdão Bachmann, que as convenções bilaterais devem ser interpretadas com prudência, não se devendo extrair do seu texto uma renúncia estadual genérica ao princípio de correlação entre a dedução das somas afectas à reserva e a imposição dos montantes pagos a final. Porém, o caso Wielockx apresenta uma diferença chave face ao anterior: aqui, o montante acumulado não deixa o património da empresa até ao 
vencimento do direito do beneficiário, que se encontra estabelecido na Holanda enquanto profissional liberal. Ou seja, os montantes da reserva são devidos por uma empresa estabelecida na Holanda - pelo que este Estado sempre poderá impor uma pretensão fiscal sobre os montantes em causa. O único obstáculo a essa pretensão fiscal vem a ser, a final, a Convenção de dupla tributação celebrada entre a Holanda e a Bélgica. Ora, tal como se firmou no Ac. Comissão/França («avoir fiscal») ${ }^{115}$, o respeito pelo conteúdo do direito de estabelecimento atribuído pelo Tratado não pode ficar na dependência de uma convenção concluída com outro Estado Membro.

O acórdão proferido viria a concluir - menos explicativamente - que a coerência fiscal não foi estabelecida em relação a um sujeito, mas foi transposta para outro nível - o nível da reciprocidade das regras aplicáveis nos Estados parte na Convenção. Como aqui a coerência fiscal é assegurada por uma convenção bilateral concluída com outro Estado, este princípio não pode ser invocado para justificar a recusa de dedução.

A jurisprudência comunitária caminharia, subsequentemente, ante a repetida invocação da excepção da coerência fiscal, no trilho do endurecimento das condições para a sua consideração. Assim, na sequência, sobretudo, dos Acórdãos Eurowings, Baars, Verkooijen e Bosal ${ }^{116}$, a relação directa implicada na coerência fiscal passou a ser entendida como a correlação entre a dedução fiscal ou beneficio de um lado e a tributação do outro, relativamente ao mesmo contribuinte

115 Acórdão de 28 de Janeiro de 1986, Comissão/França («avoir fiscal»), (270/83, Colect. p. 273).

116 Todos eles citados ap. Vanistendael, Frans, "Cohesion: the phoenix rises from his ashes», EC Tax Review, 4, 2005, onde se colhe também a súmula da jurisprudência comunitária citada em texto. 
e ao mesmo imposto, no âmbito do mesmo Estado-Membro e sob a mesma regulação fiscal.

Assim, os acórdãos subsequentes emitidos na matéria em análise fixaram-se no conceito de relação directa entre a dedutibilidade das contribuições e a sujeição a imposto das somas pagas pelos seguradores ao abrigo de contratos de seguro, procurando um conceito rígido de simetria do sistema. Ao abrigo desta casuística, apenas se reconhece que um sistema é dotado de coerência quando prevê uma "compensação directa" (Tesauro) entre a dedutibilidade das contribuições, e a tributação dos benefícios conferidos a final. Quando o sistema seja falho de simetria - não prevendo uma relação directa entre a tributação dos montantes pagos a final, e a dedução dos prémios pagos no pressente ou, maxime, não prevendo, quando não permite a dedução de prémios, uma isenção total dos montantes pagos a final (acórdãos Danner e Skandia, e Comissão, no caso Comissão c. Dinamarca) - não lhe deve ser reconhecida, desde logo, coerência intrínseca que valha a pena salvaguardar.

Por outro lado, tanto o acórdão Danner (em linha com as Conclusões do Advogado-Geral JACOBS), como o acórdão Comissão c. Dinamarca (em linha com as Conclusões da Advogada-Geral STIX-HACKL), procedem ao acolhimento da jurisprudência Wielockx. No primeiro dos casos, o Governo finlandês veio alegar, quanto a este ponto, que, do mesmo modo como existe, poderia não existir qualquer convenção aplicável ao caso em apreço, não podendo o Tribunal exigir aos Estados-Membros que concluam convenções de dupla tributação entre si. O Advogado-Geral tem então a oportunidade de precisar que o importante não é a existência de uma CDT no caso concreto, mas sim a existência de uma rede geral de convenções entre Estados-membros, com base na qual os Estados estão geralmente dispostos a renunciar ao 
direito de tributar as pensões pagas no seu território a residentes de outros países ${ }^{117}$.

No que toca à Advogada-Geral, faz-se notar que a respectiva opinião se insere já num contexto jurisprudencial de "relaxamento cauteloso"118 dos critérios rígidos anteriormente definidos; paralelamente, trata-se de um momento de reacção doutrinal contra um "activismo judicial” do Tribunal de Justiça, que se vinha materializando numa interpretação maximalista e irrestrita das liberdades fundamentais ${ }^{119}$.

Assim, a Advogada não deixa cair o argumento da coerência fiscal, por aplicação da jurisprudência Wielockx, sem que antes analise os casos de invocação da coerência a um nível nacional. Defende mesmo, na linha da jurisprudência Bachmann, Comissão c. Bélgica e Manninen, e da jurisprudência

117 No caso Comissão c. Dinamarca, os Estados-Membros envolvidos invocam que uma CDT não é parte integrante do sistema fiscal nacional: não permite ampliá-lo, mas apenas restringir a capacidade de cobrança de imposto por parte do Estado, com vista a dirimir conflitos entre sistemas jurídicos. A este ponto voltaremos mais adiante.

${ }^{118}$ A expressão é de Vanistendael, Frans, "Cohesion: the phoenix rises from his ashes», EC Tax Review, 4, 2005, p. 221.

${ }^{119}$ Cfr. SeER, Roman, «The Jurisprudence of the European Court of Justice: Limitation of the Legal Consequences?», European Taxation, vol. 46, 10, 2006. O relaxamento jurisprudencial citado em texto corresponde ao contexto dos acórdãos Manninen e Marks and Spencer e Meilicke, e das Conclusões que os antecederam (cfr., quanto a estes, últ. ob. cit). Faz-se notar que este relaxamento não chegou verdadeiramente a impregnar a jurisprudência do TJCE no quadrante que no presente trabalho se analisa - sintomático é o facto de, em sede do muito recente processo Comissão c. Bélgica, o Governo belga apenas se empenhar em apresentar justificação para um dos cinco regimes (aquele que obrigaria as empresas não estabelecidas no território à nomeação de um representante fiscal) considerados discriminatórios à luz do Direito Comunitário, e apresentar para o efeito uma justificação de cunho marcadamente pragmático (a que se prende com a eficácia dos controlos fiscais, tratada seguidamente em texto). 
sobre mais-valias latentes ( $X$ e $Y$ e Lasteyrie du Saillant) que o interesse invocado pelo Governo - garantir que as pensões serão tributadas quando as despesas com regimes de pensões tenham sido objecto de privilégios fiscais - é digno de aceitação. $\mathrm{E}$ - mais - reconhece que aqui existe a relação directa denotada no caso Bachmann entre a faculdade de dedução de contribuições e a tributação das prestações pagas, uma vez que no sistema fiscal dinamarquês as prestações pagas a residentes são tributadas conforme tenha ou não havido dedução das contribuições.

Porém, conclui, ainda assim, que a simetria detectada não basta para justificar o entrave, uma vez que não esclarece porque a Dinamarca não fez uso de meios menos restritivos - de facto, a medida afecta também as pensões pagas a residentes, cujas prestações de pensões o Estado poderá sempre tributar.

O que nos leva à segunda das excepções.

(b) Eficácia dos controlos fiscais

Já nos casos Comissão c. Bélgica e Bachmann o Tribunal defendera que o Estado-Membro tem a possibilidade de invocar a Directiva 77/799/CEE, relativa à assistência mútua das autoridades competentes dos Estados Membros em matéria de tributação directa. É, porém, no acórdão Wielockx, que mais abertamente a opõe às pretensões dos Estados, defendendo que, ao abrigo do art. $1 .^{\circ}$, n. ${ }^{\circ} 1$, da Directiva, o Estado poderá confirmar a efectuação de pagamentos junto de outro Estado Membro, já que esses pagamentos são tidos em consideração para determinação do imposto devido. O Tribunal reconhece que a colaboração devida ao abrigo da Directiva está sob reserva das normas e práticas administrativas do Estado (art. 8..$^{\circ}$ n. ${ }^{\circ} 1$, da Directiva); porém, 
sustenta que nada impede o Estado-membro de requisitar directamente ao segurado a prova que reputar necessária, condicionando o benefício ao respectivo fornecimento.

Caberia ao Advogado-Geral JacBos definir a linha argumentativa que passaria a ser percorrida pelo Tribunal nesta sede. O Advogado reconhece que, segundo jurisprudência assente, a eficácia da fiscalização tributária constitui uma razão imperiosa de interesse geral, passível de justificar restrições às liberdades fundamentais. Faz, no entanto, notar que, com as normas discriminatórias, se prosseguem dois objectivos distintos.

Primeiramente, um objectivo ligado ao controlo eficaz da dedutibilidade dos prémios, visando assegurar que o prémio é efectivamente pago, e que o regime segue as condições impostas pela lei que prevê o benefício. Neste ponto, porém, é jurisprudência assente (Acórdão Vestergaard ${ }^{120}$ ) que um Estado pode invocar a Directiva 77/799/CEE para controlar os pagamentos feitos noutro Estado. O Estado não obtém aqui base jurídica para exigir informação directamente às seguradoras, mas pode condicionar a dedutibilidade à apresentação, pelo contribuinte, de prova do pagamento pelas seguradoras. Donde o Advogado retira que a medida discriminatória se revelaria desnecessária.

Por outro lado, prossegue-se o objectivo ligado ao controlo eficaz da tributação do pagamento das pensões pela instituição. Contudo, a medida discriminatória revelar-se-ia desproporcionada, pois, na prática, excluiria os prestadores transfronteiriços do mercado em causa. Ora, o Advogado entende que o Estado pode assegurar o interesse em causa por meios menos restritivos, já que conta com três fontes de

120 Acórdão de 28 de Outubro de 1999, Vestergaard (C-55/98, Colect. p. I-7641, n. ${ }^{\circ}$ 26). 
informação para o fazer. Desde logo, o próprio contribuinte: este apresentará uma declaração de rendimentos no momento do pagamento das pensões; e, por outro lado, fornecerá prova do pagamento dos prémios, quando pedir a sua dedução - dados estes que permitirão à Administração presumir (ilidivelmente) o pagamento de pensões ao contribuinte.

Por outro lado, os Estados podem fazer trocas automáticas de informação ao abrigo da Directiva 77/799, para apurar as pensões pagas pelas instituições seguradoras a residentes de outros Estados-membros - e, assim, aferir do cumprimento das obrigações fiscais pelos seus contribuintes $^{121}$. A própria Comissão faz propostas pormenorizadas nessa matéria, na Comunicação de 2001.

Por último, o Advogado sustenta que o Estado pode garantir a informação através das próprias seguradoras, acordando com estas a concessão da dedutibilidade contra o fornecimento de informações sobre os prémios pagos. E poderá pactuar a abstenção de modificações substanciais das condições do seguro contratado. Deve presumir-se a boa fé de instituições tão fiscalizadas como as seguradoras; e sancionar - selectivamente, portanto - apenas as que actuarem de má fé, negando-lhes a dedução.

Este último ponto revelou-se o mais polémico na intervenção, não o acompanhando, desde logo, o acórdão proferido no caso. Mais recentemente, é Advogada STIX-HACKL a rechaçar a possibilidade de salvaguarda da obtenção de informação por via da celebração de acordos com as insti-

${ }^{121}$ Este ponto foi secundado pelo TJCE (Wielockx), que defendeu que as autoridades de um Estado-Membro podem invocar a citada Directiva para obter das autoridades de outro Estado membro todas as informações necessárias para determinar o montante exacto de imposto sobre o rendimento devido por um contribuinte, em função da legislação que elas próprias aplicam. 
tuições. Como o Governo dinamarquês, a Advogada nota que, dados os deveres de sigilo potencialmente adoptados, os acordos podem revelar-se inoperantes ${ }^{122}$.

Quanto a esta matéria, devem ser feitas várias observações.

Uma primeira, para dizer que a compreensão que, no âmbito da jurisprudência citada, se tem da Directiva 77/799/ /CEE, se revela distante das possibilidades efectivamente oferecidas pela sua normativa. Esta mesma ineficácia, objecto da acima citada ironia do Deputado Bartho Pronk, leva a doutrina a referir uma abordagem ingénua e superficial da Directiva em causa pelo Tribunal ${ }^{123}$.

Por outro lado, um ponto parece não ter tido o relevo adequado: o da garantia da coercibilidade dos comandos tributários do Estado face à instituição em causa. Com efeito, mesmo a admitir um funcionamento eficiente da Directiva 77/799/CEE, em matéria de assistência mútua, bem diferente da obtenção, pelo Estado titular da pretensão tributária, de informação cabal sobre o quid a tributar, é a garantia de que o logrará efectivamente tributar. Note-se que, neste ponto, e apesar de ter sido recentemente alargado à cobrança de créditos tributários em matéria de impostos directos, não se tem revelado operante o par de Directivas respeitante à assistência mútua em matéria de cobrança de créditos respeitantes

${ }^{122}$ Não obstante, a possibilidade - mais ambiciosa do que a defendida por JACOBS - de pactuar com uma instituição não residente a própria retenção na fonte do imposto devido merece o apoio de alguma doutrina (neste sentido, Schoneville, Peter, "Safeguarding pension taxation rights in cross-border situations», EC Tax Review, 2, 2005).

123 Assim, Carrero, José Manuel Calderón, e Jiménez, Adolfo Martín, «La armonización jurisprudencial de la imposición directa: las implicaciones fiscales del principio comunitário de no discriminación relación con las libertates básicas comunitarias», Manual de Fiscalidad Internacional, Instituto de Estudios Fiscales, 2004, p. 1195. 
a certas quotizações, direitos, impostos e outras medidas ${ }^{124}$. É, aliás, a Comissão a dar nota dessa ineficácia ${ }^{125} 126$.

Note-se ainda, por outro lado, que são sistematicamente consideradas desproporcionadas pelo Tribunal outras medidas de garantia do Estado face a um eventual incumprimento dos respectivos deveres pela instituição em causa - como a prestação de uma garantia (Bachmann), ou a nomeação de representantes (assim, a Comissão, em recente nota de infracção contra o Estado belga ${ }^{127}$ ).

${ }^{124}$ Directiva 76/308/CEE do Conselho de 15 de Março de 1976 (JO L 73 de 19.03.1976, p. 18), alargada ao âmbito dos impostos directos pela Directiva 2001/44/CE do Conselho de 15 de Junho de 2001 (JO L 175 de 28.6.2001, p. 17), e Directiva 2002/94/CE (JO L 337 de 13.12.2002, p. 41.) da Comissão de 9 de Dezembro de 2002, que estabelece disposições de execução da primeira. Para uma análise detalhada das disposições desta Directiva, cfr. Prats, Francisco Alfredo García, "Assistencia mutua internacional en materia de recaudación tributaria», Manual de Fiscalidad Internacional, Instituto de Estudios Fiscales, 2004.

125 Relatório da Comissão ao Conselho e ao Parlamento Europeu sobre a utilização das disposições relativas à assistência mútua em matéria de cobrança de créditos respeitantes a certas quotizações, direitos, impostos e outras medidas, COM (2006) 0043 final.

${ }^{126}$ Para um exemplo prático de outras dificuldades colocadas pela Directiva 76/308/CEE, cfr, PInTO, Ricardo de Gouvêa, "O Princípio da Legalidade do Imposto e o Procedimento em Matéria de Assistência Mútua para a Cobrança de Créditos entre os Estados-Membros da Comunidade Europeia», Temas de Integração, n. ${ }^{\circ}$ 18, 2004.

127 A validade deste expediente foi expressamente rechaçada no muito recente processo Comissão c. Bélgica, citado acima. Diga-se, contudo, que um ponto importante da argumentação do TJCE reside na existência, no seio do ordenamento jurídico belga, de uma disposição que prevê uma responsabilização pessoal do segurado pela dívida de imposto, quando o contrato, não intermediado na Bélgica, tenha sido subscrito junto de um segurador não estabelecido nem representado no território. Pelo que - ao menos, em abstracto - fica espaço para uma 
Uma terceira e última nota para referir que esta inoperância não parece ser desconhecida do Tribunal ${ }^{128}$. Parecendo, assim, deliberada a reiterada recusa jurisprudencial da aceitação da excepção da eficácia dos controlos fiscais, juntamente com a referência às potencialidades da assistência mútua. Esta orientação pode, pois, pretender servir como meio de pressão sobre os Estados, instando-os a adequar as suas legislações e administrações de modo a que a assistência possa funcionar ${ }^{129}$.

\section{APRECIAÇÃO E PROPOSTA PARA O ENQUADRAMENTO}

Em face do cenário actual de crise da Segurança Social tradicional, regista-se uma importância crescente dos esquemas

apreciação diferente em face de ordens jurídicas que não prevejam uma paralela responsabilização subsidiária do segurado.

128 Cfr. Acórdão Societé Génerale des Grandes Sources d'Eaux Minérales Françaises (C-391/96, Rec. 1998, p. 3510), citado em CARRERo, José Manuel Calderón, e Jiménez, Adolfo Martín, «La armonización jurisprudencial de la imposición directa: las implicaciones fiscales del principio comunitário de no discriminación relación con las libertates básicas comunitarias», Manual de Fiscalidad Internacional, Instituto de Estudios Fiscales, 2004, p. 1195 (AA. que, neste ponto, se acompanharam de perto).

${ }^{129}$ Face ao que se deverá perguntar se o Tribunal ainda actua nesta sede nas suas funções de órgão jurisdicional, ou se não usurpa já funções de verdadeiro actor político. Quanto à distinção e às aproximações entre a função política e a função jurisdicional, ver por todos Neves, António Castanheira, "A redução política do pensamento metodológico-jurídico (Breves notas críticas sobre o seu sentido)", Estudos em Homenagem ao Prof. Doutor Afonso Rodrigues Queiró, Boletim da Faculdade de Direito da Universidade de Coimbra, II, 1993 e Rangel, Paulo Castro, "O Legislador e o Tribunal Constitucional: o risco da redução metodológica do problema político”, Direito e Justiça, vol. XI, tomo 2, 1997. 
complementares de Segurança Social. Como não poderia deixar de ser, esta vem acompanhada de uma importância crescente das receitas fiscais atinentes a estes esquemas complementares que, assim, aumentam progressivamente o seu peso sobre o orçamento dos Estados-Membros. Paralelamente, assiste-se ao aumento progressivo do peso desta fiscalidade na esfera dos sujeitos passivos, e da consequente possibilidade de condicionamento, por constrições fiscais, do exercício das liberdades fundamentais de circulação no mercado interno europeu. Por outro lado, as respostas que, para o efeito, o sistema jurídico-comunitário disponibiliza, reconduzem-se aos actos sem valor coercivo (soft law) acima referidos, e à casuística do Tribunal de Justiça nesta matéria. Da junção destes dois vectores resulta uma elevada insegurança jurídica neste quadrante normativo.

\section{Referência breve ao Direito a constituir}

Idealmente, a insegurança jurídica detectada seria colmatada na esfera do consenso entre soberanias, através da adopção de um acto vinculativo que criasse princípios comuns em matéria de tributação directa de regimes de pensões complementares.

As linhas gerais deste acto vinculativo parecem ter já sido correctamente identificadas na soft law desenvolvida. Assim, o alinhamento dos sistemas tributários dos Estados-Membros por um regime de diferimento da tributação (EET) parece um bom princípio; bem assim, a diferenciação entre as situações de contratação fundada maioritariamente na autonomia da vontade (contratação com instituições não estabelecidas feita por residentes), e as situações em que a contratação se poderá ter fundado em contingências de lugar (contratação com instituições não estabelecidas feita por 
trabalhadores migrantes, já antes de se terem deslocado para o território), para estabelecer, no segundo grupo de casos, um princípio de reconhecimento mútuo das legislações. Por outro lado, deveria ser regulado o problema da distribuição das receitas fiscais - designadamente, através da previsão de um sistema de atribuição exclusiva da titularidade da receita a um dos Estados candidatos; ou através da distribuição proporcional das pretensões tributárias, alocando-as entre os Estados-Membros, através de sistemas de macroclearing e microclearing ${ }^{130}$.

\section{O Direito constituído: a preponderância do Tribu- nal de Justiça}

À face do sistema vigente, porém, ressalta a preponderância do Tribunal de Justiça, como único emissor de actos com força coerciva. A sua actuação nesta sede deve ser enquadrada através de duas coordenadas.

Uma primeira, para salientar que se recorta, na União Europeia, um crescente exercício de soberania tributária por parte de um órgão não representativo ${ }^{131}$. Trata-se do analisado fenómeno da european taxation without representation, simbolicamente polarizado por alguma doutrina no Tribunal

${ }^{130}$ Contendo vários modelos possíveis de distribuição de receitas fiscais, vd. Stevens, L., "Worrying about pension problems in the European Union", EC Tax Review, 2, 2003, p. 67. Em especial, quanto aos sistemas de macroclearing e microclearing, cfr. GREEF, Roland de, «EU policy for lifting pension tax obstacles does not work», EC Tax Review, 4, 2005, pp. 202 e ss.

${ }^{131}$ Quanto à matéria, vd. NaBAIs, José Casalta, Por um Estado Fiscal Suportável - Estudos de Direito Fiscal, Coimbra, 2005, especialmente pp. 198-199, em que se afloram várias questões de legitimidade levantadas pela transferência de parcelas de soberania fiscal para a União Europeia. 
concebido como "O Anti-soberano" ${ }^{132}$. Com um vício acrescido: o exercício da soberania fiscal pelo Tribunal de Justiça rege-se por critérios puramente negativos, atinentes à defesa das liberdades fundamentais do mercado único, e alheios a finalidades verdadeiramente fiscais - as atinentes à satisfação de necessidades reditícias das colectividades, através da tributação de manifestações de capacidade contributiva. Como tal, a actuação do Tribunal é puramente destrutiva, sendo este incompetente para proceder a uma integração comunitária positiva nesta sede. À destruição de normas fiscais nacionais por via jurisprudencial corresponde, pois, tão-só o abdicar de soberania fiscal por parte dos Estados-Membros. O que significa uma perda de receita líquida pelos Esta$\operatorname{dos}^{133}$, sem que haja qualquer tipo de mecanismo comunitário - desde logo, orçamental - que absorva essa perda. Por isto mesmo entendemos acima que, no actual estádio da evolução europeia, não poderia valer um princípio do reconhecimento mútuo de legislações em matéria de fiscalidade directa dos regimes complementares de pensões: o reconhecimento mútuo em matéria fiscal não pode dispensar o consentimento dos Estados-Membros.

${ }^{132} \mathrm{O}$ conceito é de Pietro Boria, que identifica e assinala o forte pendor liberalista que assinala as instituições e dinâmica da União Europeia - cfr. BORIA, Pietro, «L'integrazione «negativa» tra sistema fiscale nazionale ed ordinamento comunitario», Diritto e Pratica Tributaria Internazionale, 6, 2004, pp. 847 e ss.

${ }^{133}$ Devendo questionar-se se não se poderá verificar uma verdadeira incompatibilidade entre normas de Direito Comunitário - o comando normativo contido no acórdão do TJCE, e as normas europeias de política económica e monetária, que criam, para os Estados, limites e metas em matéria de défice orçamental e de dívida pública -, e se essa incompatibilidade normativa não constituirá uma causa legítima de inexecução do acórdão do TJCE (neste sentido, Casalta Nabais). 
Uma segunda coordenada para reconhecer que as normas fiscais que têm sido analisadas nesta sede se demonstram, pelas razões expostas em I. 2 e 3., fortemente dissuasoras da contratação com prestadores de serviços não estabelecidos no território, ou do estabelecimento ou deslocação para território diverso daquele em que se procedeu a esta contratação. Configuram, assim, normas discriminatórias, que esvaziam de conteúdo as liberdades fundamentais implicadas. Deve, pois, reconhecer-se que a jurisprudência comunitária na matéria, mais ou menos legítima, tem tido a virtualidade de chamar a atenção para a integração das economias e dos sistemas jurídicos. E, consequentemente, tem alertado para a necessidade de extensão dos critérios de justiça do sistema aos regimes de tributação de sujeitos não residentes ou não estabelecidos no território, que tradicionalmente passam ao largo do sistema tributário jurídico-constitucional ${ }^{134}$.

Assim, da compatibilização destas duas coordenadas, deve resultar que o Tribunal, lá onde descortine uma norma fiscal discriminatória (segunda coordenada), possa atender a um motivo objectivo que justifique a ilicitude da discriminação. Em sede de fiscalidade directa, parece-nos que o motivo objectivo atendível não poderá deixar de constituir um precipitado da soberania fiscal (primeira coordenada) que, sobretudo em matéria de fiscalidade directa, se há-de reconhecer aos Estados-Membros.

Sob esta compreensão, passaremos a apreciar as excepções mais relevantemente apresentadas ao Tribunal de Justiça, e expostas acima.

134 Assim, García Prats, em Prats, Francisco Alfredo García, «La Coherencia fiscal desde la perspectiva interna, internacional y comunitária», Diritto e Pratica Tributaria Internazionale, IV, 2002, pp. 412 e ss. 


\subsection{Algumas razões objectivas para a subsistência de normas discriminatórias}

(a) Eficácia dos controlos fiscais

Relativamente à excepção da eficácia dos controlos fiscais, resultou do que acima se expôs que a resposta do Tribunal de Justiça não tem sido propriamente jurídica. A sistemática recusa desta invocação resulta, assim, como um meio de pressão, exercido sobre os Estados que, na óptica da perda de receita fiscal, são os principais afectados pela integração num mercado interno: os Estados exportadores de pensões. Estes coincidirão, tipicamente, com os Estados que, prevendo o diferimento da tributação dos rendimentos associados a regimes de pensão complementares, possam ver os seus trabalhadores actuais deslocar-se para outro território, durante ou após a respectiva vida activa. No fundo, estes serão os Estados-Membros que importam mão-de-obra, política e economicamente mais fortes. No que se descortina alguma possibilidade de eficácia (se bem que não de legitimidade) do método de pressão indirecta do Tribunal.

Esta excepção tem, no entanto, um carácter puramente instrumental: apenas se poderá validamente reivindicar a eficácia dos controlos fiscais se a pretensão fiscal que se pretende exercer for legítima. Para aferir da legitimidade da pretensão tributária invocada pelos Estados-Membros que prevêem normas discriminatórias como as analisadas nesta sede, parece ter cabimento convocar o princípio da coerência fiscal.

(b) Coerência fiscal

O princípio da coerência fiscal diz respeito à articulação, numa base substantiva, atinente aos princípios de justiça 
aceites, do conjunto do sistema fiscal, considerando tanto os diferentes tributos que o compõe, como os restantes ramos do sistema jurídico em que se integra ${ }^{135}$. Assim, este princípio, correctamente entendido, não se compadece com a análise sectorial que, em sede de tributação directa, o Tribunal dele tem feito.

Como ficou dito, a noção de coerência fiscal tem sido usada pela jurisprudência numa acepção diversa, correspondente a um modo que é simultaneamente muito rígido porquanto a coerência requer o cumprimento de uma série de pressupostos - e muito vago - sem que se compreenda o propósito nem a utilidade do conceito rígido recortado pelo Tribunal.

Em matéria de fiscalidade de regimes complementares, a coerência fiscal foi definida com especial rigidez, enquanto relação directa entre dedução das contribuições e tributação. Não se percebe por que razão apenas se deva reconhecer coerência aos regimes em que vigore esta correlação estrita. Não se vê porque teria o Estado de conferir, mais do que um diferimento, uma isenção dos rendimentos, na parte

${ }^{135}$ Esta corresponde a uma compreensão conteudística do princípio da coerência, que colhe tributo nos ensinamentos de CAsalta NabAis, para quem a sistematicidade aqui implicada é uma sistematicidade substancial, decorrente de o sistema fiscal constituir uma "ordenação substancial do material jurídico-fiscal como um todo consistente, ordenado e baseado em princípios e subprincípios fundamentais e livre assim de lacunas, sobreposições e contradições, e um sistema que, por sua vez, se integra e articula coerentemente com o sistema jurídico público e com o sistema jurídico global entendidos também estes como sistemas internos [substanciais]" (NABAis, José Casalta, O Dever Fundamental de pagar impostos, Almedina, 2004, p.600). Numa concepção próxima, GARCIA Prats (in Prats, Francisco Alfredo García, «Assistencia mutua internacional en materia de recaudación tributaria», Manual de Fiscalidad Internacional, Instituto de Estudios Fiscales, 2004). 
correspondente aos frutos do capital; e menos se vê porque teria essa isenção que ser total. A coerência não é exclusiva dos modelos puros. Faz-se, aliás, notar que há poucos sistemas puros, sejam EET, ou TEE. Por outro lado, o Estado pode conferir o direito a deduções de parte do rendimento entregue como contribuição, e tributar todo o rendimento a final. E poderá, quando não confira essa dedução (vg., por o esquema não preencher os requisitos nacionais de qualificação), isentar apenas parte dos rendimentos pagos a final. O sistema em causa não deixará de ser um sistema coerente por isso. A coerência fiscal é compatível com a dupla tributação de um determinado rendimento, desde que a um nível tolerado pelos princípios de justiça do sistema. De novo se salienta que os Estados são soberanos em matéria fiscal, tendo plena liberdade para recortar o respectivo sistema fiscal, inclusivamente na mira da prossecução de finalidades extrafiscais lícitas. O Tribunal deve reconhecer a estruturação que o Estado fizer do respectivo sistema fiscal e, salvo no que toque à detecção de uma discriminação não justificada, abster-se de indagações de maior.

Urge, pois, descortinar o que se pode pretender, afinal, preservar no sistema, através da introdução da norma discriminatória. Propomos que se deva analisar a globalidade do sistema jurídico fiscal, para descortinar qual a manifestação de capacidade contributiva que se procura, com o regime fiscal em concreto, atingir. Seguidamente, deve verificar-se se, sem a inclusão da norma que discrimina dada situação que comporta elementos de extraterritorialidade, a mesma manifestação de capacidade contributiva lograria, ainda assim, ser atingida. No que a metodologia proposta se mostra dirigida a verificar se a norma discriminatória se insere na pretensão sistemática do ordenamento de proceder à tributação dessa manifestação de capacidade contributiva. 
Faz-se notar que as CDT celebradas pelo Estado devem ser consideradas para proceder a essa análise do ordenamento jurídico nacional. Nem se vê como se poderia defender o contrário: as CDT são, no fundo, actos de Direito Internacional Público clássico, que cumprem o escopo tradicional deste ramo: delimitar a soberania do Estado, nas matérias em que esta se poderia sobrepor à soberania de outros Estados. Não se vê, pois, como possam não ser consideradas parte do sistema jurídico em causa, a par de qualquer outra norma de Direito Internacional Público.

Pretende-se, como exposto, por via da análise de todos os estratos normativos, aferir da intenção sistemática do ordenamento em relação àquela manifestação de capacidade jurídica. Donde resulta o acolhimento, em alguma medida, da jurisprudência inaugurada pelo Acórdão Wielockx. Nesta sede, o Tribunal transpôs a análise da coerência para o nível das CDT celebradas pelo Estado, concluindo que estas, na maioria dos casos, prevêem normas que implicarão para o Estado a perda do direito à tributação dos montantes devidos a final. Não se acompanha, no entanto, esta jurisprudência na parte em que procura a coerência do sistema, em última linha, em face da CDT que, em concreto, se vem a mostrar competente para determinar o Estado mais titulado para proceder à tributação da pensão devida a final (no caso, tratava-se da CDT celebrada entre a Holanda e a Bélgica). Esta metodologia parece-nos incorrecta: a norma que cria a discriminação existe no sistema enquanto norma geral e abstracta - ante a verificação dos respectivos pressupostos, impede a dedução do montante entregue à instituição. Não faz, pois, sentido fundar a coerência desta previsão geral e abstracta, que opera como um prius, nas normas da CDT que venha, a final (i.e., ao tempo do pagamento da pensão), a ser aplicável ao caso. Desde logo porque não se sabe sequer, no momento em que o sistema jurídico em causa 
recusa a vantagem da dedução ao sujeito passivo, que outro Estado-Membro poderá vir a estar conectado com a situação no momento futuro do pagamento da pensão de reforma ${ }^{136}$.

Primo conspectu, o método aqui adoptado pareceria censurável - a existência de uma rede de Convenções decorre da soberania do Estado; se este abdica de receitas fiscais nos casos em que celebrou uma Convenção segundo a Convenção Modelo da OCDE (atribuindo ao Estado da residência competência exclusiva para a tributação), esse juízo não pode, de modo nenhum, ser transposto para os restantes casos. Tal pareceria, inclusivamente, equivaler ao alargamento de cláusulas de uma Convenção a situações de facto nela não abrangidas, numa técnica similar à utilizada no âmbito do princípio da nação mais favorecida ${ }^{137}$. Mais ainda - procederia à tomada em consideração, fora do seu âmbito, de normas convencionais bilaterais, que teriam por base um estrito princípio de reciprocidade.

Porém, não é isso que ocorre. Não se estende a aplicação do Tratado a casos nele não abrangidos: o que se faz, sim, é analisar todos os estratos normativos do Estado, para aferir se, num caso em que interagisse uma instituição estabelecida, o Estado se exporia ao risco de, a final, não conseguir cobrar a receita. Tal impõe que se tome em consi-

${ }^{136}$ Mais próxima do entendimento sufragado em texto está a jurisprudência pós-Wielockx, que coloca a tónica, nesta sede, na existência de uma rede de CDT entre os Estados-Membros. Cfr., por todos, as Conclusões apresentadas por JACOBS no caso Danner.

${ }^{137}$ Quanto ao - polémico - alcance do princípio em sede de União Europeia, vd. Cordewener, Axel, e Reimer, Ekkehart, "The future of the Most-Favoured-Nation treatment in EC Tax Law - Did the ECJ Pull the Emergency Break without Real Need? - Part 1», European Taxation, 6, 2006, e "The future of the Most-Favoured-Nation treatment in EC Tax Law - Did the ECJ Pull the Emergency Break without Real Need? - Part 2», European Taxation, 7, 2006. 
deração as normas das várias convenções celebradas pelo Estado em causa, com vista a compreender qual a pretensão sistematicamente prosseguida face à matéria colectável em causa. Nem parece, por último, que, por esta via, se atente contra a soberania fiscal do Estado em causa: se este inseriu determinada cláusula de repartição de competências fiscais na maioria das CDT celebradas com outros Estados-Membros, impôs aos Estados-Membros que sejam nelas contraparte o dever de lhe atribuírem tratamento simétrico. O que, parece-nos, equivale à prossecução sistemática, pelo ordenamento jurídico fiscal em causa, da tributação da manifestação de capacidade contributiva em causa apenas quando com ela possua uma conexão específica, que o torna, na óptica do próprio sistema, o ordenamento mais titulado.

\subsection{Resultados da aplicação da metodologia defendida}

Em jeito de conclusão, referem-se os resultados derivados da aplicação da metodologia proposta. Esta metodologia impõe, como exposto, que se analise as CDT celebradas pelo Estado em causa com os restantes Estados-Membros da União Europeia ${ }^{138}$, com vista a descortinar qual a intenção do sistema jurídico em causa em relação à concreta manifestação de capacidade contributiva. Assim, poder-se-á considerar:

${ }^{138} \mathrm{O}$ critério adoptado impõe que, quando, por o Estado-Membro em causa não ter ainda celebrado CDT com a maioria dos restantes Estados-Membros, a maioria das situações de repartição de competência fiscal internacional entre este Estado e os restantes Estados-Membros não for regida por CDT, mas sim por norma interna unilateral, se atente, para aferir da intenção sistematicamente prosseguida, no teor desta norma interna unilateral. Esta hipótese parece, no entanto, ter relevo meramente académico. 
(a) Ordenamentos que atribuem maioritariamente ao Estado da residência a competência para proceder à tributação a pensões.

Estes elegem a tributação com base num factor de conexão (residência do sujeito passivo) que não se prende com a localização da pagadora, e que é, ademais, móvel. Não prosseguem, pois, de modo sistemático a tributação das pensões constituídas com base em contribuições efectuadas no território. Donde decorre que a norma discriminatória não se justifica.

(b) Ordenamentos que atribuem maioritariamente ao Estado da fonte do rendimento a competência para proceder à tributação a pensões.

Antes de mais, deve deixar-se claro que esta não se trata de uma hipótese meramente académica - mas antes de uma das principais recentes preocupações dos Estados-Membros da OCDE, que presidiu à alteração, em 2005, do texto da CMOCDE. Assim, o comentário ao art. $18 .^{\circ}$ da CMOCDE ${ }^{139}$ alberga actualmente várias alternativas para construção da norma de alocação de competências, distinguindo, além do mais, entre diferentes concretizações possíveis para o critério de fonte do rendimento - desde logo, a que corresponde ao critério da fonte do rendimento enquanto critério do estabelecimento do pagador das pensões, e a que corresponde ao critério da fonte do rendimento enquanto critério

139 Cfr. Comité dos Assuntos Fiscais da OCDE, Modelo de Convenção Fiscal sobre o Rendimento e o Património, Cadernos de Ciência e Técnica Fiscal, Centro de Estudos Fiscais, 2005. 
do local da prestação do trabalho de onde proveio o rendimento constitutivo das pensões.

(i) Quando a maioria das CDT adoptadas pelo Estado consagrar o critério da fonte do rendimento, enquanto critério do estabelecimento do pagador das pensões, a discriminação das contribuições entregues a instituições não estabelecidas parece inserir-se na coerência intrínseca do sistema: o estabelecimento da instituição no território é essencial para atingir uma manifestação de capacidade contributiva, articulando-se com as normas que a perseguem.

(ii) Quando a maioria das CDT adoptadas pelo Estado consagrar o critério da fonte do rendimento, enquanto critério do local da prestação do trabalho de onde proveio o rendimento constitutivo das pensões, a questão será menos líquida. Deve notar-se, porém, que, entendendo que é fonte quando no respectivo território tiver sido prestado o trabalho do pensionista, o Estado não abdica de tributar as pensões construídas com base em rendimentos de trabalho feito no território. Pelo que a legitimidade da garantia dessa tributação através de uma norma que discrimine com base no estabelecimento decorre do resultado de um juízo de proporcionalidade.

Para a densificação deste juízo de proporcionalidade, deixamos três notas finais. A primeira, chamando a atenção para que os órgãos da Comunidade tendem a fazer um juízo de proporcionalidade demasiado exigente, rejeitando sistematicamente os vários expedientes possíveis (como o recurso a representantes fiscais, ao mecanismo de claw-back, ou 
à prestação de garantia). Uma segunda, alertando para que o Tribunal (ao contrário do parece ter pretendido em sede de tributação de mais-valias latentes) não poderá condicionar a eficácia da cobrança do tributo em causa à conclusão de acordos entre os Estados, uma vez que esta conclusão não se encontra na disponibilidade do Estado-Membro "infractor". E uma última, para concluir que esta configura uma matéria in fieri, dependente do grau de evolução e de eficácia dos meios processuais de auxílio mútuo ao dispor dos Estados-Membros. 
(Página deixada propositadamente em branco) 


\section{REFERÊNCIAS BIBLIOGRÁFICAS}

BORIA, Pietro, «L'integrazione «negativa» tra sistema fiscale nazionale ed ordinamento comunitario", Diritto e Pratica Tributaria Internazionale, 6, 2004.

Brabanter, Véronique de, "The Danner case: elimination o Finnish tax obstacles to the cross-border contributions to voluntary pension schemes», EC Tax Review, 3, 2003.

Buchanan, James M., «Opportunity cost», The New Palgrave - A Dictionary of Economics, Vol. 3, 1998.

Burda, Michael, e Wyplosz, Charles, Macroeconomics, A European Text, Oxford University Press, 1993.

Campos, João Mota de, Direito Comunitário - III Volume - O Ordenamento Económico, Fundação Calouste Gulbenkian, 1997.

Carrero, José Manuel Calderón, e Jiménez, Adolfo Martín, «La armonización jurisprudencial de la imposición directa: las implicaciones fiscales del principio comunitário de no discriminación relación con las libertates básicas comunitarias», Manual de Fiscalidad Internacional, Instituto de Estudios Fiscales, 2004.

Cinelui, Maurizio, Diritto della Previdenza Sociale, G. Giapichelli Editore, 2003.

Comité dos Assuntos Fiscais da OCDE, Modelo de Convenção Fiscal sobre o Rendimento e o Património, Cadernos de Ciência e Técnica Fiscal, Centro de Estudos Fiscais, 2005.

Cordewener, Axel, e Reimer, Ekkehart, «The future of the Most-Favoured-Nation treatment in EC Tax Law - Did the ECJ Pull the Emergency Break without Real Need? - Part 1", European Taxation, 6, 2006. 
«The future of the Most-Favoured-Nation treatment in EC Tax Law - Did the ECJ Pull the Emergency Break without Real Need? - Part 2», European Taxation, 7, 2006.

Cunha, Patrícia Noiret da, A tributação directa na jurisprudência do Tribunal de Justiça, Coimbra Editora, 2006.

Farmer, Paul, «The Court's case law on taxation: a castle built on shifting sands?», EC Tax Review, 2, 2003.

FeHr, Hans, e Jess, Heinrich, "Who Benefits from the Reform of Pension Taxation in Germany?», Fiscal Studies 28, 1, 2007.

Geneva Association, «The four pillars program and its evolution 1987-1998», The Geneva Papers on Risk and Insurance: Issues and Practice, A. 23, n. ${ }^{\circ}$ 88, 1998.

Grupo de Trabalho criado por despacho de 1 de Maio do Ministro de Estado e das Finanças, Reavaliação dos Benefícios Fiscais - Relatório do Grupo de Trabalho criado por despacho de 1 de Maio do Ministro de Estado e das Finanças, Cadernos de Ciência e Técnica Fiscal, n. ${ }^{\circ}$ 198, Coimbra, Almedina, 2005.

Gomes, Nuno Sá, Teoria Geral dos Benefícios Fiscais, Cadernos de Ciência e Técnica Fiscal, n. ${ }^{\circ}$ 359, 360 e 362, Centro de Estudos Fiscais, 1991.

Gorjão-Henriques, Miguel, Direito Comunitário, Almedina, 2007.

Greef, Roland de, «EU policy for lifting pension tax obstacles does not work", EC Tax Review, 4, 2005, pp. 202 e ss.

HinNEKENS, Luc, «European court goes for robust tax principles for treaty freedoms. What about reasonable exceptions and balances?», EC Tax Review, 2, 2004.

Lyal, Richard, "Non-discrimination and direct tax in Community Law», Ec Tax Review, 2, 2003.

Marchessou, Philippe, e Pérez, Susana Aníbarro, «Direct taxation and fundamental freedoms of the Community: an approach to the contribution of the European Court of Justice», Diritto e Pratica Tributaria Internazionale, 4, 2004

Nabais, José Casalta, O Dever Fundamental de pagar impostos, Almedina, 2004. 
Direito Fiscal, Coimbra, Almedina, 2005.

Por um Estado Fiscal Suportável - Estudos de Direito Fiscal, Coimbra, 2005(b)

Neves, António Castanheira, «A redução política do pensamento metodológico-jurídico (Breves notas críticas sobre o seu sentido)", Estudos em Homenagem ao Prof. Doutor Afonso Rodrigues Queiró, Boletim da Faculdade de Direito da Universidade de Coimbra, II, 1993.

Nunes, A.J. Avelãs, Economia $-I I-O$ Crédito, Serviços de Acção Social da U.C., 2004.

Oliverra, Arnaldo Filipe da Costa, Fundos de Pensões. Estudo Jurídico, Almedina, 2003.

Pinto, Ricardo de Gouvêa, "O Princípio da Legalidade do Imposto e o Procedimento em Matéria de Assistência Mútua para a Cobrança de Créditos entre os Estados-Membros da Comunidade Europeia», Temas de Integração, n. ${ }^{\circ}$ 18, 2004.

Porto, Manuel Carlos Lopes, Teoria de Integração e Políticas Comunitárias, Almedina, 2001.

Prats, Francisco Alfredo García, «La Coherencia fiscal desde la perspectiva interna, internacional y comunitária», Diritto $e$ Pratica Tributaria Internazionale, IV, 2002.

"Assistencia mutua internacional en materia de recaudación tributaria», Manual de Fiscalidad Internacional, Instituto de Estudios Fiscales, 2004.

Quelhas, José Manuel Santos, «A Agenda 2000 e o Sistema de Financiamento da União Europeia», Temas de Integração, n. ${ }^{\circ}$, 3. ${ }^{\circ}$ Volume, 1998.

Rangel, Paulo Castro, «O Legislador e o Tribunal Constitucional: o risco da redução metodológica do problema político", Direito e Justiça, vol. XI, tomo 2, 1997.

Ribeiro, José Joaquim Teixeira, Lições de Finanças Públicas, Coimbra Editora, 1995.

Schlunk, Herwig J., "A lifetime income tax», New York University Law and Economics Research Paper Series, Working Paper N. ${ }^{\circ}$ 02-06, 2005.

SCHONeville, Peter, «Safeguarding pension taxation rights in cross-border situations», EC Tax Review, 2, 2005. 
SEER, Roman, «The Jurisprudence of the European Court of Justice: Limitation of the Legal Consequences?», European Taxation, vol. 46, 10, 2006.

Stevens, L., "Worrying about pension problems in the European Union", EC Tax Review, 2, 2003.

VAnistendael, Frans, "The compatibility of the basic economic freedoms with the sovereign tax systems of the Member States", EC Tax Review, 3, 2003.

"Cohesion: the phoenix rises from his ashes», EC Tax Review, 4, 2005.

Wathelet, Melchior, «Direct taxation and EU law: integration or desintegration?», EC Tax Review, 1, 2004, pp. 2 e ss.

Weber, Dennis, «In Search of a (New) Equilibrium Between tax sovereignity and the Freedom of Movement Within the EC», Intertax, 12, vol. 34, 2006.

Whitehouse, Edward, «Fonds de pension et mesures de incitation fiscale», Risques, n. ${ }^{\circ}$ 23, 1995.

Xavier, Alberto, Direito Tributário Internacional, $2^{a}$ Edição, Almedina, 2007.

Yoo, Kwang-Yeol, e Serres, Alain de, «Tax Treatment of Private Pension Savings in OCDE Countries», OECD Economic Studies n. ${ }^{\circ}$ 39, 2004/2.

\author{
Maria Inês de Oliveira Martins \\ Assistente Estagiária \\ da Faculdade de Direito de Coimbra
}

